DOE/NASA20366-2

NASA TM-82721

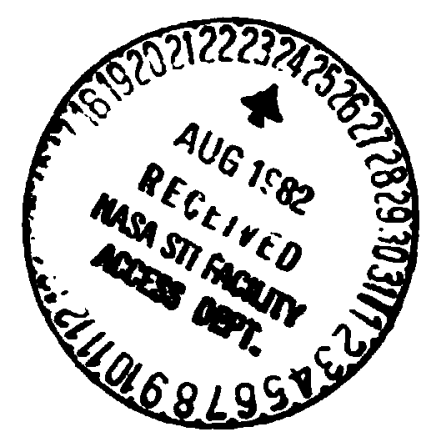

\title{
Experience and Assessment of the DOE-NASA Mod-1 2000-Kilowatt Wind Turbine Generator at Boone, North Carolina
}

(HASA-TA-827 Z1) EXPERIENLE ANC ASSESSHET OF THE DOE-XASA LOD-1 2000-RILCHATT HIND TURBINE GENEEATCR AT EOONE, NCETH CAECLIMA Fina: Report (NASA) $55 \mathrm{p}$ \&C AO4/GF AO 1

John L. Collins and Richard K. Shaltens

Nationai Aeronautics and Space Administration Lewis Research Center

and

Richard H. Poor and Robert S. Barton

General Electric Company

Valley Forge Space Center

April 1982 


\section{CONTENTS}

Page

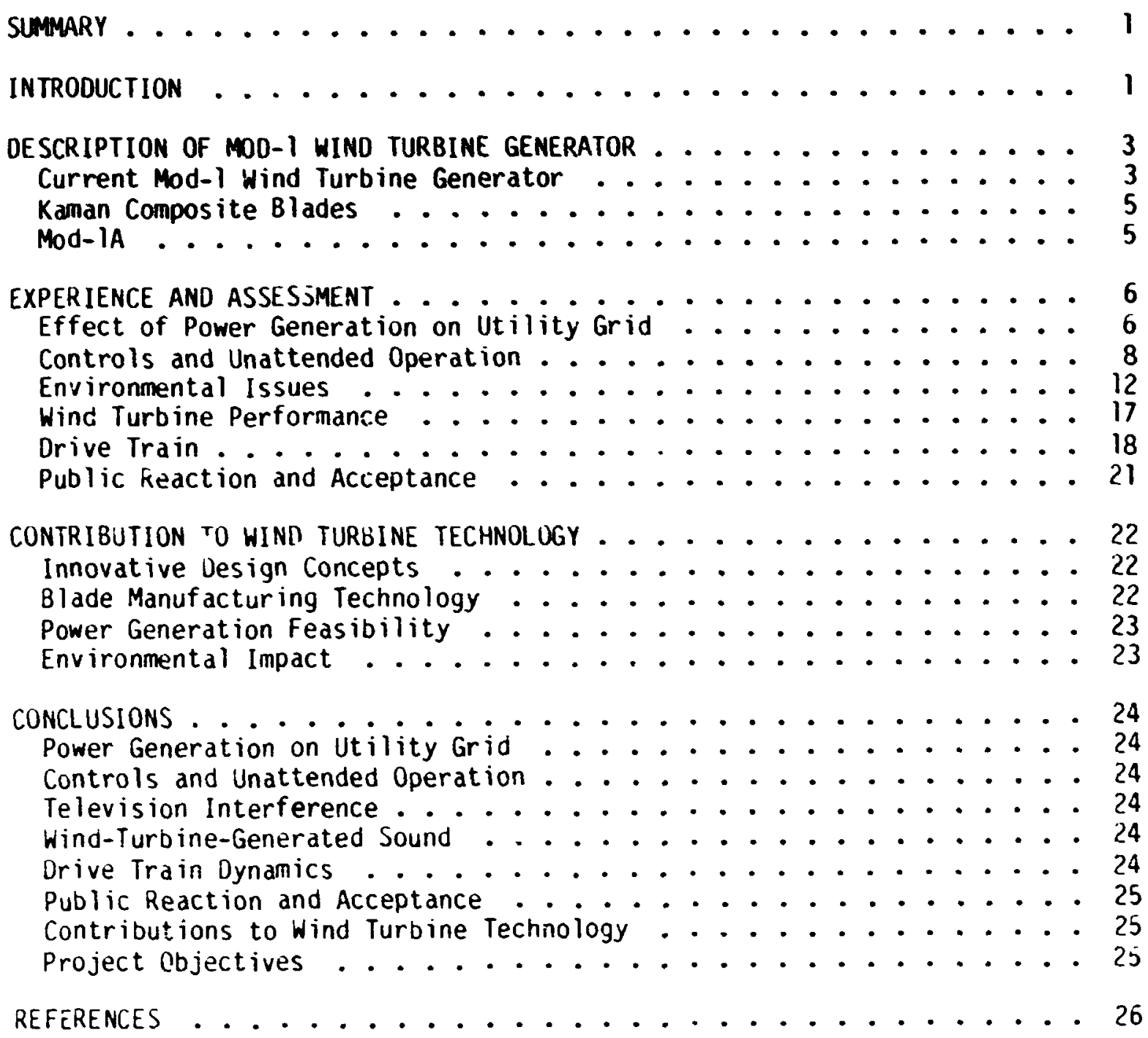




\title{
EXPERIENCE AND ASSESSMENT OF THE DOE-MASA MOD-I 2000-KILOMATT
}

\author{
MIMD TURBINE genERATOR AT BOONE, MORTH CAROLIMA \\ John L. Collins and Richard K. Shaltens \\ Mational Aeronautics and Space Administration \\ Lewis Research Center
}

Richard H. Poor and Robert S. Barton
General Electric Company
Valley Forge Space Center

\section{SUMARY}

The broad objectives of the Mod-l program are defined, including the background information leading to the inception of the program. Activities on the Mod-1 program began in 1974, and the turbine was dedicated in July 1979. Rated power generation was accomplished in February 1980. The Mod-1 wind turbine is described in this report. In addition to the stee operated on the wind turbine, a composite blade was designed and manufactured. During the early phase of the manufacturing cycle a Mod-lA configuration was designed that identified concepts such as partial span control, a soft tower, and upwind teetered rotors that have been incorporated in second- and third-generation industry designs.

The Mod-l electrical system performed as designed, with voltage flicker characteristics with in acceptable utility limits. Power output versus wind speed has equaled or exceeded design predictions. The wind turbine control system was operated successfully at the site and remotely from the utility dispatcher's office in Lenoir, N.C. During wind turbine operations, television interference was experienced by the local residents. As a consequence, operations were restricted. Although not implemented, two potential solutions were identified. In addition to television interference, a few local residents complained about objectionable sound, particularly the "thump" as the blade passed behind the tower. To el iminate the residents' objections, the sound generation level was reduced by $10 \mathrm{db}$ by reducing the rotor speed from $35 \mathrm{rpm}$ to $23 \mathrm{rpm}$. During January 1981, bolts in the orive train fractured. A solution has been iuent if ied but not implemented as yet. During the past 2 years the public reaction toward the Mod-l Wind Turb ine program has been overwhelmingly favorable. This includes the vast majority of Boone residents.

\section{INTROOUCTION}

The Federal Wind Energy program administered by the Department of Energy (DOE) has as one of its goals the development of the technology for practical, cost-competitive wind turbines that can be used to supply significant amounts of electric energy. As a part of the wind turbine development, the Lew is Research Center of the Nat ional Aeronautics and Space Administration (NASA) was given the responsibility to carry out the Mod-l prograrr. The General Electric $C_{0}$. (GE), under contract to Lewis, designed, built, and installed the Mod-I wind turbine at Howard's Knob in Boone, N.C. The Blue Ridge Electric Memtership Corp. (BREMC), a rural cooperative with headquarters in Lenoir, N.C., received the power generated by the Mod-l wind 
iurbine; and $\triangle K E M C$ operated the wind turbine remotely from the oispatcher's office in Lenoir.

The overall objective of the 2-m Moo-l progran was to obtain early operational and performance oata that could be useu in the oesign of seconageneration cost-competitive wind turbines. The mod-l wino turoine was the first megawatt-size machine in the Federal winu Energy program to proouce electric power from wind energy. Specific project objectives were as follows:

(1) To obtain operational and performance data for a megawatt-size wino turbine in a utility-operated application

(2) To oemonstrate unattended, fail-safe operation

(3) To involve a utility as user and operator

(4) To ioentify maintenance requirements for large wind turbines

(5) To involve inuustry in the uesign, fabrication, and installation of d wind turbine

(6) To identify component and subsystem moaifications that wil' reauce cost, inprove reliability, ano increase perfornance

(7) To assess public reaction to and acceptance of large wina turbines

(8) To demonstrate compatibilicy witn utility requirements

A very significant benefit of the Moo-l program was the discovery chat under some conaitions the winu turbine enitced an objectionable sound level to 10 families living near the site. Hethoas to characterize the souno in order to establish acceptable sound standaras and to reouce the sound levels became a significant part of the Moa-l progran.

The chronology of the major events in the mod-l program is as follows:

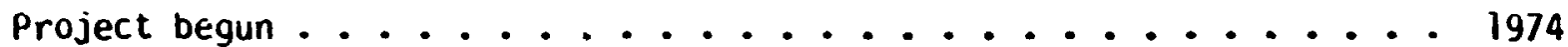

Contract placed with General Electric Co. .......... July 1976

First rotation ................ May 1979

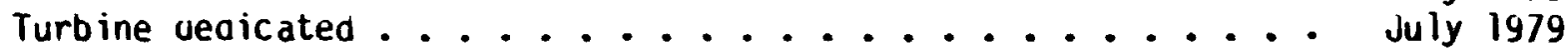

Turo ine synchronized with BKEMC network........ September 1979

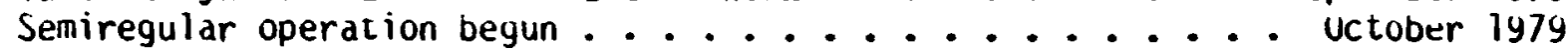

Turbine acceptance testing completea ........... January l98u

Utility training completeu .............. reuruary lysu

Full power $(2000 \mathrm{kw})$ generateo ............. February is\&u

Reduceu-rutor-rpni trouification completeu ........ wovethiver lyou urive train problem developea............ January lysi

Ther? have been inally participants involveo with the mod-1 proyran that have contributed to it, success. K. Puthofi, MASA Lewis Kesearch Center, ano $k$. barchet, General Electric Co., mace outstanoing contributions to the progran. Successful completion of the progran would not have been possiole without project support from G. Ayers, Jr., ano K. Lumyarner of BKLinc in worth Carolina. 


\section{UESCRIPTION OF MOD-I WIND TLKBIME GERERATOK}

\section{Current Mod-1 Wind Turbine Generator}

The Mod-1 2000-kH wind turbine generator is mounted on top of a truss tower with its horizontal rotor axis $140 \mathrm{ft}$ high. Its two blaces are $200 \mathrm{ft}$ in diameter (fig. l) and located oownwino of the tower. The nacellebedplate, which supports and encloses all equipment mounted on top of the tower, is driven through a yaw-bearing assembly that rotates about the vertical axis of the tower in response to changes in the wind direction. The tower is $12 \mathrm{ft}$ square at the top ano $48 \mathrm{ft}$ square at the bottom and is anchorcd to reinforceo concrete footings at each leg. Figure 2 shows the macnine installeo on Howard's Knob, in Boone, M.C. The elevation at the site is approximately $4500 \mathrm{ft}$ above sea level. The original uesign specifications are presented in table 1 .

The wind turbine assembly consists of the rotor assembly, the orive train - bedplate assembly, the yaw assemily, and the cower (fig. 3 ). The turbine rotor initially nperated at $35 \mathrm{rpm}$ and generated $2000 \mathrm{~kW}$ of electric power in a $25.5-\mathrm{mph}$ wina (at $30 \mathrm{ft}$ ); it was moaified to $23 \mathrm{rpm}$ and $1350 \mathrm{kw}$ in Noverber 1980. The hub ano blades are connected to a low-speed shart that drives a gearbox. In the gearbox tne low-speea shaft speed was increased from $35 \mathrm{rpm}$ to $1800 \mathrm{rpm}$ and later from $23 \mathrm{rpm}$ to $1200 \mathrm{rpm}$. A high-speeu shaft connects the gearbox to the alternator. The entire system weighs $655000 \mathrm{lb}, 335000 \mathrm{lb}$ in machine weignt ano 320000 lo in tower weight. Table II presents a weight breakdown of the machine. The major components are described in the following subsections.

Kotor assembly. - The rotor assembly consists of three major subassemblies: the biades, the hub assenibly, and the pitch-change mechanisu. Each blaae is attached to the hub through a three-row, cylinorical roller bearing that permits the full pitch of the blade from the power position $\left(0^{\circ}\right)$ to the feather position $\left(90^{\circ}\right)$. olace pitch is controlleo by nyaraulic actuators operating through a mechanical linkage with sufficient capacity to feather the olaaes at an average rate of $8 \mathrm{aeg} / \mathrm{sec}$.

The blaoes are constructea of a monocoque, weldeo-steel leaaing-eage spar ano an derouynanically contoureo, polyurethane foam afterbooy with bonded 301 stainless-steel skins (fig. 4). Measuring $100.8 \mathrm{ft}$ long with a tapered planform ano thickness, the olave uses an NACA 44XX series airfoil with a thickness ratio varying from 20 percent at the tip to 33 percent at the root. The olages, which weigh approximately 2150016 eacn, are assemvled in six main sections. spar welds are located at five stations, as are the trailing-eage-section splices. A transition piece is weloed to the spar to provide the blade continuity to the interface with the hub. A longitudinal stiffner and chorowise webs are welded in the spar to provioe buckling strength. ballast weights are used at each blaoe tip for static and uynamic balance.

The hub assemoly consists of a huo barrel ano a nuo tailsnatt (fig. 5 ). The hub barrel houses the pitch-change bearing and supports the oldaes at a $9^{\circ}$ cone angle. The tailshaft joins the barrel with a $120^{\circ}$ sadale flange ano a transition to the circular main-bearing seat ano flange. The inain rotor bearing is shrink fitted to the hub tailshaft and boltea to the beaplate adapter to form the rotor-beaplate interface.

The pitch-change mechanism positions the blades in response to commanos from the cuntrol system. It consists of hydraulic actuators, swing links, a thrust ring and bearing, and two blade pitch rods (fig. 6). The stationary 


\section{CPBGIIII FAGE IS}

OF POOR QJALITY

hyoraulic actuators translate fore and aft motion to the rotating (35 rpm) pitch assenbly through a thrust ring. This assembly is supported by both stationary and rotating swing link arms to maintain clearance from the lowspeea shaft and thus allow the fore and aft motion to change the pitch of the blade through the pitch rods.

Urive train - bedplate assembly. - The drive train assembly consists of a low-speed shaft and couplings, a three-stage yearbox, ana a hign-speed shaft tnat drives the alternator (fig. 7). The high-speed snatt incorporates a dry-disk slip clutch for protection against torque overlodus and a disk brake that will stop the rotor in the event of an cverspeed condition and also is used to nolu the rotor in a parkeo position. The entire assembly is supportea on a beaplate ana enclosed in an aluminum nacelle tairing for protection.

Yaw drive assembly. - Yaw rutation of the machine to align with the wind is provided by the yaw orive, which consists of upper and lower structures, a cross roller bearing, uual hydraulic orive motors, and six hydraulic braxes (rig. 3). Each yaw motor orives a pinion mesning with a ring gear on the inner race of the yaw bearing. The yaw brakes dampen dynanic excitations in yaw motions while the nacelle is being driven. These components are houseo in a yaw structure that interfaces between the wachine and the pintle structure of the tower.

Tower. - The steel tubular truss tower ifig. 11 is made of seven vertical bays with uracing vesignea for volted field assemoly. Tubular members were usea to reduce "tower shaoow" loads on the blades as they pass the tower. The tower was vesignea to proviue stiffness in the lateral allu torsional moves. The bending frequency is 2.8 times the rotor operating frequency, ano the torsion frequency is 0.5 times the rotor operating frequency. The maxilium design wind load is $150 \mathrm{mph}$. All tower memuers were fabricateo from $\dot{A} 3 j 3$ steel, which provides good low-temperature fracture toughness.

The tower is supported by separate foundations for each of its four legs. Because of the deadweight of the wind turbine, relatively small tension loads are developea in the founation. Each leg is securea by eight 1.5-in.-oiameter anchor Dolts hookeo at a oepth of 30 in. into the foundation. Tower baseplate shear loads react through a nonshrink grout to a lip on the foundation that is tied into reinforcing bars in the founuation.

Control system. - The control system for the wind turbine includes a pup Digitai Equipment Corp. $11 / 34$ computer locateo in the grouno enclosure at the bare of the tower. The PUP 11/34 interfaces with two PUP 11/04 microcompu rs. Une PUP $11 / 04$ is locateo in the concrol enclosure, ano the other in the nacelle. The control system provides unattended safe and reliable operation of the wing turbine plus the features of a uata logging system. It will autonatically start, operate, and stop the macnine, align it with the wina, anu provioe oispatcher control through a telepinone link. In audition, if the control system aetects any operation or macnine anomaly, it is progranmed to safely shut the wind turbine oown. Figure y presents a simplified control schematic. Kefe;ence 1 provides auditional Hoo-l intormation on the actual installation ano checkout of the machine. neferences $c$ to 4 provide a detaileo description and a summary of the design calculations, incluaing an analysis of failure moves and eftects. 


\section{ORIGIIALI FAGE IS \\ OF POOR QUALITY}

\section{Kaman Composite olades}

Two composite rotor blades, designed and built specifically for operation on the Mod-1 wind turbine by Kaman Aerospace Corp., bloomf ield, Conn., have recently been completed. The design, manufacture, and ground testing of these blades are described completely in reference 5. These blades were developed as the second phase in MASA's on-going evaluation of the applicability of composite construction for very large wind turbine blades. The first phase served to develop the technology for such blades and demonstrated this in a 150-ft test blade, which was completed and static tested in 1978. This was the largest composite rotor blade ever constructed and successfully demonstrated the potential of this material. The final blades, illustrated in figure 10, are fully compatible with the Mod-l wind turbine and possess dynamic characteristics equivalent to those of the present steel blades. The blade's main structural member is the D-spar, which reacts all primary loads and comprises over 70 percent of blade weight. The spar was constructed by the transverse filanient tape (TFT) process, first used for a rotor blade in the 150-ft-blace program. An epoxy resin is used for its superior fatigue strength, compatible with the 30-year vesign life of the blacies. The afterboay portion of the blade, a lightweight structure that completes the airfoil cross section, comprises upper and lower panel members. These are of sanowich construction, inner and outer fiberglass skins with a honeycomb core of resin-impregnatea kraft paper; the panels vary in thickness from $l$ in. to 3 in. An aaapter fitting of welded steel construction is perinanentiy installed at the inboara spar end by means of a bolt attachment. The blaces incorporate lightning protection that is capable of withstanoing 200 000-A strokes. The lightning protection is configurea to minimize its adverse effect on the inherentiy low-television-interference characteristics of composites. The new blade also includes an ice detection aevice, as well as a polyurethane paint system and leading-edge protection to withstand environmental effects.

$$
\text { Mod-IA }
$$

Shortly after the rlod-l wind turbine final aesign was completed, a traoe-off study was begun on a conceptual design that woula take advantage of innovative design approacnes that were identified during the mod-l design experience but that could not be incorporateo in the mod-1 because of scheaule and cost constraints. This design concept, which was callea mod-1A, had as its basic objectives the reduction in weight from 327 to 200 tons and in the cost of energy from 18 to $5 \& / \mathrm{kW}-\mathrm{hr}$ (ill 1978 dollars), see taole III.

In the trace-off stuay, three canaidate systems were identified, as shown in figure 11.

Configuration 3, which has as its najor characteristics a teeterea huo, two upwina blaues witn partial span control, an integral, parallel-shaft gearbox structure, an inclineo rotor axis, and a "soft" shell tower, was selected. The mod-lA overall configuration is shown in figure 12. A view of the upper portion of the tower and nacelle is shown in figure 13. Although the mod-lA was not built, many of the concepts icuentified in this trade-off study have been incorporated in second- and thira-generation designs. 


\title{
EXPERIENCE AND ASSESSMENT
}

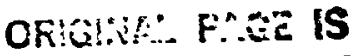 \\ OF POR: C.MA':TY
}

\section{Effect of Power Generation on Utility Gria}

Wind turbine power generation system. - The Mod-1 wind turbine power generation system is shown in figure 14. It consists of a symchronous yenerator, a contactor, and a stepup transformer, with auxiliary power connections on the line side of the contactor. High-resistance grounoing is provided for the generator to limit ground-fault current levels. The contactor is an unfused 5-kV-class motor starter with a latching circuitbreaker mechanism. Its 50-mVA interrupting rating is more than is neeoeo to clear faults fen by either the generator or the utility system. The stepup transformer is delta connected at $4.16 \mathrm{kV}$ with a generator $Y$-connection. At the 12.47-kV uiility side the $Y$ connection is solialy neutral grounded and has lightniag arrestors and a fused load-break switch for disconnection and protection of the transformer.

The generator has two controls on its output: real power and excitation. Real power is controlled at the turbine rotor through full-span blade pitch control, and excitation is controlled through a voltage regulator and auxiliary equipment that feeds the generator shaft-mounted brushless exciter. Power control is inactive for wind speeas below ratea wind speed, and at these speeds the Mod-l output will fluctuate with wino speeo and deliver as much power as it can extract from the wind. For wina speeas above rated wino speed the controller regulates average power output to the level of the system torque rating with an integral-plus-lag-power-error type of feedback control. The excitation system controls yoltage prior to synchronization with the grid. Voltage, power factor, or reactive power control moves may be selected after synchronization. Most operation has been in the reactive power control mode with a 250-kVAR delivery to the grid. A stadilizer circuit is also used to moaulate the excitation in response to hub speed fluctuation.

blue Kidge Electric Membership Corp. system. - The Blue Kiage Electric Membership Corp. (DREMC) 12.47-ky aistribution system arouna boone, N.C., is shown in figure 15. The Mod-1 wind turbine is connected to the Howara's Knob circuit, one of three radial feeders from the boone substation. Other connections are possible with manual switching, to feed the Sherwood or Houno Ears substations. The effective impeaance seen by the wina turbine generator to an infinite bus equivalent is 0.142 per unit on the originaliy installed generator base of 2 MVA.

The Boone substatior, rias a 12.47-kV-bus voltage regulator and a recloser on each feeder. A voltage blocking device was adoed to the Howard's KnoD circuit recloser to prevent nonsynchronous reclosing with the wino turbine generator. The substation transformer rating was raised from 6 liva to 7.5 MVA in Uctober 1980 by BREMC and has had a 45-min peak load of $8.1 \mathrm{MVA}$ recorded in 1981. About 3600 customer accounts are served oy the boone sudstation, of which 660 are on the Howard's Knob circuit. A resiaence locateo $1400 \mathrm{ft}$ from the wind turbine is the closest load. The most voltagecritical load is a water filter plant with 350 total motor horsepower and 67 percent undervoltage aropout on the circuit breaker. Tne banboo circuit, connecteu to the Boone $12.47-k V$ bus, has about 1370 accounts, including a hospital ano inotor loads at a sewage treatment plant.

utility requirements. - Maintaining constant voltage, proviaing service, and protecting equipnent from faults are the primary operating goals of

$B R E M C$. BKEMC operation maintains voltage within a 5-percent band by using 
regulators and other devices and limits the size of customer motors that can be full-voltage started. A stanaard voltage flicker chart, shown in figure 16, is appropriate for dynamic voltage fluctuations that elicit negligible complaints and therefore are acceptable to most utilities. The utility grid acts as a large source/sink at constant frequency relative to the wind turbine, and large power fluctuations in the connecting line are not objectionable to the utility as long as they do not cause objectionable voltage fluctuations in the line.

General operating experience. - BKEMC has received no complaints associated with hod-1 power or voltage aisturbances. To quantify the voltage characteristics on the BREMC system, voltage recorders were temporarily installed by BREMC on the 12.47-kV line at the boone suostation and on a circuit supplying power to the meteorological tower that is about $200 \mathrm{ft}$ from the mod-l wind turbine. Typical traces from these recoroers are shown in figures $1 /(a)$ and $(b)$, respectively. Figure $17(c)$ shows the line-to-line voltage ano phase current at the generator during a transient (breaker closure followed by breaker opening) that occurreo during the same perioo that voltage was recorded at the boone substation and at the meteorological tower circuit. Although the site voltage fluctuation was almost 7 percent, the voltage variation at the boone substation was not discerniole on the recorder traces. Most of the recorder voltage change is due to voltage regulator action at the substation, ratner than to wind-turbine-prodiced excitation.

A typical site record of uperation at $35 \mathrm{rpm}$ is shown in figure 18. There is a time-scale change part way through ine recora that increases the chart speed by five times for better high-frequency detail. The power set point is $1000 \mathrm{~kW}$ during this tine and auring the first $60 \mathrm{sec}$, and the pitch angle is off the electronically controlled stop at about $1.5^{\circ}$ in order to regulate. For tne balance of the record, pitch angle is constant. Power trace oscillation represents wind fluctuations plus drive train naturalfrequency intermittent oscillation and the two-per-revoiution response due to the tower shadow. The blade flap bending trace shows the inpulsive tower shadow response that occurs once per revolution per blade for the Mod-1 downwina configuration. Voltage fluctuation is limited to 11 percent with frequencies of two per revolution and one per revolution by the power system stabilizer circuit (speed sensor and voltage regulator). The drive train fundamental mode damping is increased by the power system stabilizer action, and the resulting voltage fluctuation is well within acceptable limits. The reactive power trace is similar to the voltage trace and illustrates that an average $65 \mathrm{KVAR}$ (lagging) was being delivered to the BKEMC system.

The amplituve of two per revolution (fig. 18) on the real power trace is about 15 percent peak to peak, wnich is better than the design value vaseo on the system aynanic simulations inae auring the vesign phase. The on-line behavior of the Mod-l electric power system at $35 \mathrm{rpm}$ showed no evidence of instability and exhibited adequate well-dampeo decay in transient windinduced oscillations at the drive train fundamental frequency.

A typical site recura of power parameters from recent operation at

$23 \mathrm{rpm}$ is shown in figure 19. The voltage at the generator bus varies about 4 percent overall because of the generator power angle changes resulting from arive train oscillation with a less-than-opt imum nower system stadilizer circuit. A generator bus variation of 4 percent corresponds to a critical bus variation of 2.2 percent which is well within the sniall-gust flicker criterion. Keactive power oscillates adout $150 \mathrm{kVAx}$ arouna the 2! J-kVAR nominal set point, also because of orive train oscillations. 


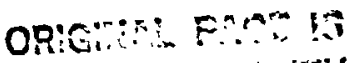

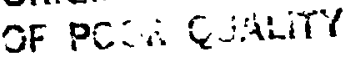

The reai power and rotor shaft torque traces are in phase, which illustrates that drive train oscillations are at the torsional fundanental frequency. The frequency of the higher amplitude oscillations is $0.42 \mathrm{~Hz}$, which is near the one-per-revolution frequency of $0.383 \mathrm{~Hz}$. Kesponse at two per revolution, $0.77 \mathrm{~Hz}$, is also seen periodically at lower amplituces. Shifts in aveiage power at lower frequencies are oue to wino speed changes or blade pitch changes. Sone oscillatory behavior only occurred at $23 \mathrm{rpm}$ with the present control system.

Assessment. - The Mod-l wind turbine's electrical generation system has performed as expected on the BKEMC system. Voltage flicker characteristics are within typical utility limits. Power variation at $35 \mathrm{rpm}$ is about 15 percent peak to peak and is of no concern to the user utility. Power cscillations result primarily from the two-per-revolution response to tower shadow. Electrical performance showed no evidence of instability and exhibited an adequate, well-dampeo response to transient wind-induced oscillations. Oscillatory behavior at the orive train fundamental frequency is higher at $23 \mathrm{rpm}$ than at $35 \mathrm{rpm}$.

\section{Controls and Unattended uperation}

Modes of operation. - The Mod-1 wind turbine was designea to operate in three contro! modes: manual operation, automatic operation, ana unattended operation with remote control. The first mode, manual operation, enables the on-site wind turbine operator to perform specified maneuvers in order to conauct maintenance and test functions while of $f$ line. Included in these maneuvers are (1) orientation of the nacelle at any yaw angle (angle relative to wind turbine vertical axis), (2) orientation of the blades at any angle relative to the hut axis of rotation, (3) orientation of the blade at any pitch angle, and (4) rotation of the wind turbine off line at any speed up to and including rated speed. A complete list of functions is given in table IV.

The second mode or operation, autcmatic operation, enables the wind tur bine uperator at the site to start up the wind turbine, to set the output power ievel, to cotain data, and to shut aown the wina turbine. All other control functions are performed automatically without operator

intervention. The purpose of this mode is to generate power to the utility grid while the wind turbine is controlled by an operator located at the site. If the wind conditions are within cut-in $V_{C I}$ and cut-out $V_{C U}$ wind velocity, the wino turbine will generate power at the operator-prescribed set point (or less depending on the wind velocity conditions) in a fully automatic manner.

The third and last control mode, unattended operation with remote control, enables the operator located at a remote site to start up the wind turbine, to set the power output level, and to shut down the wina turbine. The purpose of the mode is to operate the wind turoine from the utility dispatcher's office at Lenoir, N.C., 30 miles from the wind turbine site, with no operators at the site.

Control system. - To understand how the wind turbine operates in the manual and automatic modes (controlled at the site or from a remote loca-. tion), a description of the overall control system is appropriate at this time. The primary control mechanism of the mod-l is olade pitch control. Uff line the primary control parameter is rotor speed, and on line it is generator power. In general the control system performs all sensing, recoraing, utility communication, signal conditioning and buffering, and 


\section{OR:AliM: F:D is \\ OF PCOR QJALITY}

commana functions for the wind turbine. A block diagram that illustrates the overall functional arrangement of the equipment to perform the control functions is shown in figure 20 . The upper block of equipment is located in the nacelle, and the two lower blocks are located in the control enclosure. The wina turbine systen provides precision analog control of blade angle and yaw orientation in response to wind direction, wina speed, power set point, rotor speed, and other operational parameters. The control of most functions depends on multiple inputs and varying "logic" within an operating mode. The control and recording unit (CRU), with its data gathering and processing capability, is the system master control?er. CKU logic is used to determine whether to operate on the basis of operator commands and control parameters. As an example, the operational envelope of wind speed versus yaw error (difference between nacelle direction and wind direction) is shown in figure 21. Manual control, with input from a keyboard, is also processea through the CRU to el iminate human control errors and thus provide maxinum machine and personnel safety.

Uutput power level is controlled by comands to the analog pitch contro? loop in the servocontroller. This permits considerable flexibility in operation. A discrete power level can be maintained, the system can track wind speed and maximize power output continuously, and the CRU logic eniaivies the system to come on line automatically and autonomous?y witen wind conditions permit. Also the control system provides maximum energy capture capability at below rated wind speeds and maintains safe control of rotor speed at above rated wind speeds. Sufficient diagnostic data can be automatically recoraed so that the causes of shutdowns or anomalnus operation can be readily determined. Operating procedures ior the Mod-1 require that diagnostic data always be automatically recorded.

The control system has the following specific functions:

(1) Control the rotor biade pitch angle to startup; supply subrated power at wind speeds tetween 11 and $25.5 \mathrm{mph}$ and rated power at wind speeds between 25.5 and $35 \mathrm{mph}$ (nominal)

(2) Control the nacelle position through the yaw drive and yaw brake actuators

(3) Condition, buffer, and optionally record sensor signals

(4) Provide operator interface

(5) Provide remote dispatcher control by means of ths telephone line

(6) Provice supervisory, alarn, ano shutoown control logic

These functions are performed fully automatically without an operator in attenoance at the site to accommodate internal system variables as well as external variables such as winc speed and direction. A detailed set of control system functions during startup and generation are shown in table $V$.

As stated previously, control of blade pitch angle is the precominant aynamic function that directly controls rotor torque. A uetailed listing of pitch control modes required to operate the wind turbine, with associated operating conditions, is shown in table VI. The startup sequence to synchronize with the utility grid is shown in figure 22. 


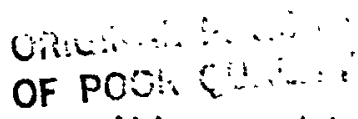

The second control function positions and holds the nacelle by actuating the hydraulic yaw motors and the yaw brakes. To be able to collect the maximum wind energy possible, the nacelle must be rotated about its vertical axis and aligned with the wind direction. Control logic for the four wind speed regimes is given in table VII. If the average yaw error has persisteo above $5^{\circ}$ for $5 \mathrm{~min}$, the yaw hydraulic motors are turned on, in the appropriate direction, until the corrected angle is less than $1^{\circ}$. Because of the slow 1/4-deg/sec yaw rate, a shorter persistence period is selected as the yaw error increases, as shown in figure 23. This change in sensitivity allows higher energy capture during a changing wino direction.

The wind turbine is a complex electronechanical system that must be protected from internal failures and from external forces such as wind, ice, snow, and temperature extremes. For this reason, fail-safe logic has heen designed into the controls. The types of shutdowns and the criteria for each shutdown are shown in table VIII. Backup direct-acting sensors are also provided for overspeed control of the emergency feather and brake systems.

Experience. - One of the main objectives of the Mod-l program was to demonstrate the feasibility of remote wind turbine cortrol by the utility. Communication for remote operation is accomplished at 300 baud by using Southern Bell Co. telephone lines. Initial remote control was attainea during acceptance testing in January 1980 ana was regularly used thereafter when the wind turbine was not allocated to souna and television interference testing or undergoing major modifications. Remote control operacion usually occurrea between 11:30 p.m. and 8:00 a.m. After remote control operation procedures were established, phone line communications were found to be acceptable. Several dispatchers at BREMC were trained and operated the wind turbine successfully. As experience was gained, additional machine operational parameters were maoe available to the remote operator to provide a more thorough understanding of the machine operating state. Typical learning problems were experienced, including remote-terminal hardware failures, occasional switch adjustments, and initial operator unfamiliarity with control procedures. Since the wind turbine control logic was based on a fail-safe philosophy with numerous safety checks, personnel and terminal hardware proolems did not result in wind turbine misoperation or inalfunction. Significant and beneficial controls information, data, ana experience were acquired during the wind turbine operation phase. The most significant problen in the wind turbine control system was computer-to-computer communications. This problem occurred between the Uigital Equipment Corp. (UEC) PUP $11 / 34$ control and recording unit (CRU) and two POP 11/04's located in the wind turbine nacelle multiplexer unit (MU) and in the control enclosure ground multiplexer unit (GMU), respectively. The occasional loss of communication between computers resulted in unscheduled wina turbine shutdowns. When communication failures occur, operator error message statenents such as nacelle multiplexer link fail, transmit buffer overrun, or connect fail are printed on the operator terminal to aid in aiagnostic proceuures. Communications are controlled by UEC commercial computer electronics Doards ( CAMC-11's), which contain a microprocessor. The kinds of communication failures can be understood by examining the definitions of operator error message statements. A connect fail occurs when a NMU or GMU fails to return an acknowleagment of an attempt to communicate by the CKU. A nacelle multiplexer link fail occurs when the time for data transfer between either the NMU or the GMU and the CRU is excessive. If a successful data transfer 
occurs, a buffer is released for reuse. When the data transfer is unsuccessful, a buffer is not available for transfer cf additionai intormation and a transmit buffer overrun occurs.

Before active investigation and solution implementation of the "link failure" problem began in March 1980, communication malfunctions were experienced about 8 days per month. As causes were determined and solutions implemented, malfunctions were progressively el iminated by November 1980. The specific steps taken to eliminate computer-to-computer cormunication malfunctions were numerous. The initial step in March 1980 was to install siower byte-rate OMC-1i microprocessur boards, $50 \mathrm{kilobytes} / \mathrm{sec}$, in place of the existing faster OMC- 11 nicroprocessor boards, 1 million bytes/sec, in the control enclosure - nacelle link. The slower byte-rate boards are more tolerant of brief comounication lapses. As a result these new boards reauced link failures but did not eliminate them.

Second, in April 1980 the allowable cycle time for computer communication was increased to 350 misec from $150 \mathrm{msec}$. This reduced link failures further, particularly in the actomatic mode. To improve the manual mode, the cycle time was increased to 600 inser in iray 1980 . Subsequer,t to this modification, link failures consisted primarily of transmit buffer overruns, with the preponderance occurring during lightning storms and yaw maneuvers. In spite of several electrical measurements indicating that the yaw slip ring was performing acceptably, an auxiliary cable bypassing the slip ring was installed for diagnostic tests. Since there were no further link failures while the bypass control cable was instailed, it was concluded that the last major cause of communication irregularities was a deteriorated slip ring. In May 1981 a slip rirg manufacturer's inspection revealed salt oeposits on the silver-plated contacts. This was the second such detection of salt deposit on the slip ring contacts even though prescribed cleaning procedures were used about 22 months earlieir. based on the pattern of link failures, it was concluded that the slip rings were being progressively contaminated with a salt deposit. Since the Boone Mod-l wind turbine is not in a salt air climate, it is speculited that some fluids used in wind turbine operation or maintenance, such as hydraulic fluid, may contain a salt additive and might have inacvertently spilled into the slip ring assenbly ouring the initial assembly period. It is planned to investigate the chemical composition. of all Miod-l fluias to confirm this hypothesis. Since the May cleaning no link failures have occurred with the control systen that can be attributed to the yaw slip riny.

Another lesson learned was the need for qualified and readily available expertise for the computer systen preventive and corrective maintenance. Hod-l site operation records indicate that for the period March-lecember 1980 expert computer techricians were required 13 times. Unly during July ana August was no preventive and corrective ...uintenance raquired. In addition to preventive maintenance every 3 months, computer services were needed for refair of the line printer, replacement of electronic boaras, replacement of the olsk orive, repair of the tape unit, and repair of the remote terminal. On-call maintenance service was purchased from DEC since they supplied the total computer system including peripherals.

Operation with a minicompucer-based control system proved to be highly flexible in inaking system changes quickly and inexpensively. As ar example, after it was concluded that the system rotor speed had to be slowe? to reduce the sound generation to acceptable levels, the centrai processor logic within the CRU was easily modified to operate the wind turbine at $23 \mathrm{rpm}$ with a 1200-rpm generator. The control system flexibility was furtrer 


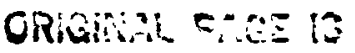

OF POQ? QLuinty

demonstraten when the wind turbine was operated at 23 rpm with the existing 1800-rpm generator (prior to a generator change) while generating power to a temporary load bank rithout changing control hardware.

Also during routine testing, the CRU data base was temporarily changed numerous times in minutes to suit test requirements. Finally, since the Mod-l was the first development vehicle planned to aemonstrate tine feasibility of a megawatt-size wind turbine, a number of unexpected events oicurred that required ata for analytical investigation. The data archive feature of storing histurical operati unal data on magnetic tape within the CRU proved useful in investigating, analyzins, and eva?uating all facets of syste" operation. This systen records on tape all "traficic" between the CRU and each of the remo'e multiplexer units (KMU's), all "traffic" between the CKU and BREMC, all communications between the CRU and the on-site operator, ana all changes in data states. Recorded data are available for troubleshooting through the playback processor when the wind turbne system is not operating. An RKO 5 aisk has been allocated to recora operational data for analysis if the magnetic tape recorder is not available.

Assessment. - The rod-1 control system should be more appropriately referred to as an operational control, data acquisition, recording, and display system. Based on the wind turbine system performance ouring and after the program acceptance test, a general assessment is that the control system performed as designed. The wind turbine was operated successfully in all throe modes, including the unattended, remote control mode from the BKEMC aispatcners office in Lenoir, N.C., about 30 miles from the Howara's Knob site. Perhaps the greatest advantage of the Mod-l control system is flexibility, and this was a key requirement of the Mation's first megawatt-size research and development wind turbine generator. With the experience gained from the mod-l system, second-generation machines are using a nore simplified and durable microprocessor.

\section{Environmental Issues}

While conducting the initial checkout of the wind tarbine during the winter of 1979-80, complaints were received from resiaents in the immediate vicinity that the machine was proaucing interference with television reception and was emitting an annoying sound. Machine operations were restricted to minimize these disturbances to the affected areas while evaluation studies were begun and established experts hired to properly evaluate these environmental issues. It should te noted that only 10 households have comp'ained atout noise, and 35 householas have noted some television interference out of a community with a population of over 10000 .

The wina turbine is located on top of howard's Knob (elevation, $4420 \mathrm{ft}$ ), a heavily wooded mountain in the Blue kidge Chain of the Appalacnian. Mountains. Howard's Knob is locateo outside the city limits of boine (elevation, $3266 \mathrm{ft}$ ) in Watauga County in northwest North Carolina near the Tennessee border. It is important to realize that the mountainous ter rain (see rig. 24, local map of Boorie) surrounding the Mod-l site has a significant influence on how these environmental issues affect the residents in the community.

Television interference. - Throughout 1980, television reception was investigated and evaluated at areas where complaints of interference were received and at other locations in the general area to fully identify the scope of the prob?em. Communications consultants were used to conduct these test programs and investigations. The geographic orientation of the nine 
television channels available to the Soone residents are illustratea in figure 25. All of the transmitters are over $46 \mathrm{~km}$ from the wind turbine. Table IX lists the nine network channels available in Bowne, the station locations, the network affiliation, the effective radiated (visual) powers, the transmitting antenna locations, the distances from the wind turbine, and the compass bearings.

Discussion: The quality of television reception oepends on the signaito-noise ratio of the receiver, the receiving antenna used, and the television signal strength. To determine the quality that is possible in the Boone area, the amiient field strengths were measured at the test siies on all of the available television channels. Since most of the homes are located in the valleys below the tops of the surrounding hills, it was expectea that the television signals would be weak as a result of shadowing by the terrain. This proved to be the case; and according to the industry specification of the signi:= needed for high-quality service (good reception), the reception of most channels at almost all homes woula be classified as poor. The severity of wind turbine interference with television reception depends on the ratio of the wind turbine's scattered signal strength to the ambient signal strength at the location in question. The television signal strengths were determined at the base of the wind turbine tower and at the top of the nacelle approximately $150 \mathrm{ft}$ above the ground. The signal strengths at the nacelle ano at the base of the wino turbine were similar, and the signals received on all channels were quite strong. Because the signal strengths are so strong at the site of the mod-1, the reflected signal throughout the interference regions will have a large potential for causing television interference.

The blades of a wind turbine can interfere with television reception by producing video aistortion. No audio aistortion has been observed. When the wind turbine is operating, the interference is caused by the timevarying amplitude moaulation of the received signal proauced oy the rotating blades. In the neighborhood of a wind turbine, the signals scattered by the blades combine with the primary broadcast signal to create a form of timevarying multipath signal, thereby amplitude modulating the total receiveo signal. The modulation wavefo,ms consist of synchronous pulses, and since ach blade of the wind turbine contributes independently, the pulses repeat at twice the rotational frequency of the machine rotor. If sufficiently strong, these extraneous pulses can distort the received picture. When the blades are stationary, the scattereo signal may appear on the television screen as a ghost whose position (separation) depenas on the difference between the tine delays of the primary and scatterea signals. A rotation of the blades then causes the ghost to fluctuate, which can result in a more objectionable picture. In such cases, the raceived picture displays a horizontal jitter in synchronism with the blide rotation. As the interference increases, the entire fuzzy picture shows a pulseu brightening, ano still larger interference can disrupt the television receiver's vertical synchronization, causing the picture to roll over ( $f$ lip) or even break up. This type of interference occurs when the interfering signal reaches the receiver as a result of scattering of the broad iace of a blade and is calleo backwara-region interference. In the forward interierence ringion, when the wino turbine is almost in line between the transmitter and the receiver, there is virtually no difference in the times of arrival of the primary and secondary signals (fig. 26). The ghost is then superimposed on the undistorted picture and the video interference appears as an intensity (brightness) fluctuation of the picture in synchronism with the blaue 


\section{ORIGINRL ERTE :S \\ OF POOR QUARitr}

rotation. In all cases the amount of interference depends on the strength of the scattered signals relative to the prinary one, and the interference decreases with increasing distance from the wind turbine. Aithough interference decreases with increasing distance from the achine, in the worst cases it can still produce objectionable video distortion at distances up to a few kilometers. At a given distance from the wind turbine, the interference increases with increasing frequency; and the interference is worse on the upper VHF channels.

Test results and tentative solutions: As a result of the measureo data and the analysis performed by the University of Michigan, Department of Electrical Engineering (refs. 6 and 7), the following observations were wade:

(1) In the city of boone and the surrounding area, the ambient field strengths are low on all of the ayailable television channels. Even with the wind turbine stationary, the quality of reception is poor; and a highperformance antenna is not sufficient to arake it good.

(2) With the wind turbine operating, varying anounts of television interfererce were found at all test areas and on all television channels. One reason for this is the large increase in reflecteo field strength in the test area due to the Mod-1 wind turbine. With a high-performance antenna, the backwaro-iegion interference observed at the test areas was juaged to be acceptable; however, interference in the forwara region was judged to be unacceptable.

Four tentative solutions to the Mod-l television interference problem were considered:

(1) Restrict machine operating time to avoid operating ouring prime teievision time.

(2) Use special high-performance antennas at the affected residences.

(3) Extend cable television into affected areas.

(4) Rebrozacast television signals via television translators to the affected areas.

Restricted wind turbine operation to avoid operating during prime television time was implemented early in 1980 to minimize the inconvenience to the boone residents. This was considered only as a temporary solution and for the long term would not be economically advantageous. High-perionmance antennas would be economically attractive but tiould not completely solve the proolem. They would eliminate interference in the backwara interference region but would be totally ineffective in the forwara interierence region. The city of boone and the densely populated areas around the city nave access to cable television. Cable service has not been extended to all the valleys and mountainous areas surrounding boone and the Howara's Knob area because it is not attractive from a business viewpoint. These were the areas where the wind turbine caused the teievision interference problems.

Jonn $F$. $X$. Browne ano Associates made an in-depth investigation of the use of television translators as a potential solution in the boone area. A television translator is a rebroadcast station operating with a low-power transmitter, usually 10 to $100 \mathrm{~W}$. The translator converts tne conventional 
VFF television signals to specific UfF television channels and rebroadcasts the signals to a specific area. The translator approach depends on the interrelationship of any variables, including (1) terrain, (2) power, (3) antenna height and pattern, (4) operating frequency, (5) viewers' reception facilities, and (6) localized objects, such as buildings and trees, that restrict reception. The television signal quality, within the affected area adjacent to the wind turbine site, provided by the translator system wou's be equivalent to that provided by a high-power television station in a metropolitan area. These broadcast stations are considered to be a "secondary" service by the FCC and are licensed on the basis of noninterference with regular television broadcast stations. Further details of the translator application can be. aviewed in reference 3.

Sumary: Cabie television and rebroadcast via translators both would provide technically adequate solutions to eliminate television interference in the affected areas surrounding the Mod-l wind turbine on Howard's Knob. Special antennas will not solve the television problem associated with wina turbines. Kestricting the operating time for a wind turbice is not considereo an acceptable solution to television interference.

Sound. - During the initial checkout operation of the wind turbine in the fall of 1979, a few complaints were received from local residents that the machine was emitting ar. objectionable souno. In some instances, it was reported that the sound was accompanied by vibration of residential houses. The character of the souns was described by affecteo residents as an audible "thump" (similar to a large heart beat) at a repetition rate equal to twice the blade rotational speed. The "thump" occurs when a blace passes behind the tower. In adition to the thump, a typical wina turoine "swishing" sound can be heard in the background that is relatively inconspicuous.

Initial complaints were sporadic and as a consequence difficult to correlate. This inconsistent pattern of complaints was partially due to the seasonal nature of the boone resiaential community in the vicinity of the wind turbine. To date, 10 specific residences within a 2 -mile radius have complained about objectionable sound, with only two residents complaining persistently. The residents complaining about objectionable sound also complained about television interference.

As a result of the sound complaints, a joint MASA-BREMC-GE decision was wace to limit operation of the wino turbine to daylight hours with the exception of brief periods during the night for necessary sound measurements. To gain community understanding, BREMC conducted informative meetings with affected residents in Marich 1980. At that time consideration of a rotor slowdown to $23 \mathrm{rpm}$ later in the year was mentioned as a potential method to reduce sound levels. Also during 1980, BREMC released articles to the local press informing the general public of the status of the sounu situation.

Testing program and results: During the early winter of 1979 the Solar Energy Kesearch Institute (SERI) conjucted a limited sound survey at the wind turbine site and near a few affected residences. This survey confirmea the existence of ranoom sound levels at the resioences that could be considered the basis for complaints. This is especially true for a rural community that has a very low level of background sound. The initial measurements also revealed that additional in-depth tests would be required to obtain a basic understanding of the snuna generation and propayation mechanisms. Initial concerns in adcition to the basic sound level were lowfrequency souna and structural vibration. At this time local atmospheric 


$$
\begin{aligned}
& \text { C.. } \\
& \text { OF FOCR QUADITY }
\end{aligned}
$$

and terrain characteristics were suspected of intensifying sound at some locations.

The first in a series of three in-depth sound measurement and analysis prugrams was conducted during February, marth, and April 1980. This pro9r3m, which was implemented by GE and SERI, measured sound pressure level as a function of time and frequency. These measurements were made at the wind turbine and in and near tha home of a resident that had registered sound complaints on several occasions. In addition to sound measurements, vibration levels in the home of ne resident were measureo. To evaluate the meteorological effects on sound propagation, Penn State University and University of Virginia personnel measured atmospheric parameters of temperature and wind velocity as a function of elevation. In reference 11 the authors discuss a theo.etical model of refracture focusing and measured sound levels at the Mod-l site.

The results and basic data from this test program were documentea in reference S. Test data inoicated that ojjectionable sound was basically a sequence of impulses at a blade-passing-the-tower repetition rate, as shown typically in fiqure 27. A typical sound-pressure-level-versus-frequency curve is shown in figure 28 as measured wi ihin $50 \mathrm{ft}$ of the wind turbine when it was generating $1000 \mathrm{kH}$ on February 12, 1980. A comparison of the souno pressure level outside the house of a local resident versus that insige the house can be obtained by comparing figures 29 ano 30 .

It was concluded from this initial test program that the frequency range of primary interest with regard to complaints was from 5 to $70 \mathrm{kz}$. The conaition referred to as a "thump" is cnaracterized by an increase in sound, especially in the 20 - to $30-\mathrm{Hz}$ range. Any oDjectionable house vibration is ove to low-frequency acoustic energy in the same frequency range (20 to $30 \mathrm{~Hz}$ ). A mathematicai model developed as a sound level predictive $=001$ suggesieo that appreciable atmospneric focusing of sound energy could be typical of the Hnwara's knob area. Finally, it was preaictea that a reauction in rotor speed from $35 \mathrm{rpm}$ to $23 \mathrm{rpm}$ would reduce souna; however, the amount of sound reouction might be marginal with respect to complaints Decause affected families had been sensitized.

The secona sound measurement program was conducted with ine wind turbine in a temporary configuration operating at $23 \mathrm{rpm}$ and generating power into a portable resistor type of load bank. The results indicated an avei age $8-$ to 10-db reduction in sound power level from the $35-\mathrm{rpm}$ sound power levels (fig. 31). These measurements suppliea supporting aata to cont inue with the program plan to reouce the wino turbine rotor speed to $23 \mathrm{rpm}$ by replacing the 1800-rpm synchronous generator with a 1200-rpm generator.

The third sound measurement program was conoucteo in January 1981 after the 1200-rpm generator had been installed and when the wind turbine was generating power into the utility grid at $23 \mathrm{rpm}$. Statistical data were recorded in the 31.5-Hz-octave-bana near field (approx 240 to $270 \mathrm{ft}$ from the wina turbine center) at three locations and in the far field at two of the local residences. Uata were recoroed continuously, and statistical distributions were automatically generateo for half-hour perioos so that sound pressure level aata coulo oe plotted as a function of the percentage of the time that a specific level occurred. A typical curve is shown in figure 32 witn a 50-percentile-near-field (at the wina turbine) souna pressure level of 71 do as compareo with a minimum ambient level of 54 ab.

The results of this test program have been reported in reference 10 by K. J. Wells of the General Eiectric Co. At one residential area the average souna pressure level ( 50 perientile) varied from 64 do when a complaint was 
registered to 51 db when no camplaints were received (fig. 33). At the second resiciential location the average sound level (50 percentile) was $49 \mathrm{oB}$ while the wind turbine was on line (fig. 34).

From tree results of this test phase, it can be concluoed that the sound level in the 31.5- $\mathrm{Hz}$ octave band is a reasonable choice for a convenient measure of wind turbine sound. The sound levels in the near field were essentially constant for a given yaw angle and wind velocity. The sound levels measurea in January 1981 correlated closely with the prior 23-rpmload-bank tests from the summer of 1980. Much of the time the far-field ievels in the $31.5-\mathrm{Hz}$ bano mere about as would be expecteo if spherical divergence were assumed. No complaints occurred under these conaitions. The condition referred to as "thump" seems to be caused by occasional atmospheric focusing due to unusual wind and temperature gradients. At one farfield location, measureo levels as much as $25 \mathrm{~dB}$ above that expecteo by spherical divergence occurred, and in such cases the far-field level exceeded the near-field level.

Assessment: Complaints about objectionable sound from the wina turbine mere restricted to an area with a radius of 2 miles and to 10 resiaents. Only two of these residents complained persistently. because of the concerns of the local boone residents, wind turbine operation was curtailed during early evening hours with a few exceptions. The character of the sound is repetitive, similar to a heart beat. Reducing the rotor speed to $23 \mathrm{rpm}$ reduced the sound level by about $10 \mathrm{db}$ near the wind turbine as predicted. Statistical analysis of sounu measurements at the wind turbine rotating at $23 \mathrm{rpm}$ indicate that the average sound (50 percentiie) was about $70 \mathrm{~dB}$ and that 1 percent of the time the sound level was about $77 \mathrm{db}$. Mear the home of one of the local residents who was more persistently annoyed the average sound level was about $52 \mathrm{db}$, ana exceeded 60 ad for 1 percent of the time during the test period. At the same location during a 1.5 -hour perioo wten a complaint was received, the average sound level was $03 \mathrm{db}$ ana 1 percent of the time the sound exceeded $77 \mathrm{~dB}$. The measured sound levels at local residences, which on rare occasions are equal to or greater than sound levels measureo at the wind turbine, substantiate the notion that atmospheric focusing is a significant factor in causing the limited number of complaints at boone. Another interrelateo factor in causing souno complaints is wind-turbine-proauced television interference that creates an awareness on the part of a sensitized resident of wind turbine operation through a visual medium.

\section{Wind Turbine Performance}

The periormance of the Moo-1 wina turbine was originally reported in 1980 in reference 12 . The experimental data used in this performance analysis of generator power output versus wind speed at the hud were preliminary at that time, but the machine was operating as preaicted. Figure 35 illustrates the same plot as reference 12 except that there are substantially more data samples included in each plotted point. The machine's perfornance follows the design prediction very well. A few aata points from the reference plot and figure 35 are above the design line, an indication that the machine has a higher overall efficiency than was originally preaicted.

As expected, losses occur in the drive train and rotor of the macnine. The generator, bearings, and gearbox are stanoara components and their manufacturers have well-documented efficiency curves. 


$$
\begin{aligned}
& \text { OR: } \because \because \because: 3 \\
& \text { of PLAis Q Q A }
\end{aligned}
$$

The resulting efficiency increase is attributed to the higher than predicted aerodynamic performance of the blaces. The original Mod-l wind turbine performance calculations may have been conservative because of the lack of blade aerodynamic performance data, particularly with regard to blade surface effects. A more detailed performance analysis of the Hod-! wind turbine has been reported in reierence 13.

\section{Drive Train}

Drive train dynamics. - In March 1980, trade-off siucies were begun to identify near-term practical methods of reducing the sound level emitted by the wind turbine. Reducing the rotor speed was selecteo as the option to be implemented. This change could be accomplished by changing synchronous generators (from $1800 \mathrm{rpm}$ to $1200 \mathrm{rpm}$ ) and thus reducing the rotor speed from 35 rpun to $23 \mathrm{rpm}$. This option was selected because it yielded the best set of advantages: (1) minimum changes to the machine, (2) minimum time sineoule to complete the machine changes, (3) minimum costs, and (4) high probability of solving the sound problen. A solution had to be selected early so that hardware procurement could be begun for installation during the fall of 1980 for subsequent testing during the winter of 1980 . Selecting the reauced-rotor-speed option in March 1980 provided 6 months to procure the haraware and schedule the change.

viscussion: During the analysis and design period for the reducedrotor-speed option, it was realized that the once-per-revolution excitation frequency $(0.383 \mathrm{~Hz})$ is close to the drive train natural frequency of $0.41 \mathrm{~Hz}$ when the wind turbine is operating at $23 \mathrm{rpm}$. This situation presented the possibility that if the blades were not well balanced or aeroaynamically trimmed, an undesirable one-per-revolution response might be experienced in the drije train. The wind turbine was operated at 23 and $35 \mathrm{rpm}$ in a manual mode and synchronized to the utility grid at $35 \mathrm{rpm}$ without any indication of an inbalance between blades. Therefore, since there was no positive inaication of an impending problem associated with this proposed change, it was decided to proceed with the rotor speed reauction.

During the period of time when the wind turbine was operated at $35 \mathrm{rpm}$, the machine performed well, was compatible with the utility grid, and was dynamically very stable. When the reducea-rotor-speed option was completea, our concerns during the analysis and design period became a reality. Uuring gusty wino perioas the machine experienced power swings of 940 percent about the control set point during intermittent time periods. Although this did not affect the utility or its customers because of the relative size of the utility and the power generated by the wind turbine, power swings of this magnituae are undesirable. Power swings of this magnitude on the wino turbine woulu reduce the iife of some components, primarily the gearbox, and on comercially produced wind turbines would add unnecessary capital equipment costs to withstano 40-percent-fatigue overload conditions. To avoid potential damage to the wino turbine gearbox, the power set point was temporarily limited to $1000 \mathrm{k} *$ until the power swings could be reduced.

wina turbine generators have a lightly damped torsional mode, generally below $1 \mathrm{~Hz}$, that is deternined by turbine inertia ano snaft stitfness. The generator inertia for the change from 35 rpin to 23 rpitincreasea from $50.51 \mathrm{~b}-\mathrm{ft}-\mathrm{sec}^{2}$ to $69.7 \mathrm{lb}-\mathrm{ft}-\mathrm{sec}^{2}$, which was an insignificant orive train inertia change. The frequency and damping ratio of the first torsional mode are influenced cy four factors: arive train, power regulation, power system 


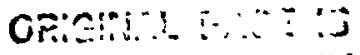

OF POUis Qunitity

stabilizer, and hub speed feedback. The first torsional ande of the wind turbine drive train is $0.41 \mathrm{~Hz}$, which primarily represents the movement of the hub and blades against the effective stiffness of the shafting, gearbox, and generator conection to the power system. Since the electrical stiffness between the generator and the utility power system is higher than the mechanical stiffness between the rotor and generator, the displacement of the turbine rotor on the first torsional mode is much greater than the displacement of the generator rotor. The stiffness ratio of the utility power system to the wind turbine drive train system is 8.33 to 1 . Electrical dasping at the generator is difficult because the generator rotor is a minor part in the displacement caused by the first torsional mode. Shaft damping can be effective but would require extensive structural changes.

Assessmer,t: Damping at the rotor can be achieved by a more active blade angle control. A control system analysis of a Mod-1 system indicated that damping of the first torsional mode could be increased from 5 percent to 25 percent of critical damping by adding a signal in phase with the hub speed deviation to the output of the blade pitch angle controller. This would require a mre active pitch hyaraulic system, which could increase maintenance on this system at some time in the future since the system was not originally designed for the more active duty cycle associated with the aoded hub speed control signal.

During January 1981, the wina turbine was operated at the reducea-power set point while sound measurements were made in order to evaluate the machine operating at $23 \mathrm{rpm}$. The program operating schedule calleo for completion of the evaluation and denonstration of the 23-rpm control system problem in February 1981. A problem developed in the drive train on January 20, 1981, that terminated operations. The problem is discussed in the next section.

Orive train problem. - Un January 20, 1981, the wind turbine experiencea a failure of 22 studs in the arive train. Specifically these studs attacheo the low-speed-shaft gear coupling to the rotor hub. Figure 36 illustrates the general orive train arrangement on the wina turbine and ioent if ies where the bolted joint is located. When the rotor hub separated from the lowspeed drive shaft and the remaining portion of the orive train, the safety system initiated feathering of the blades, which stopped the rotor hub and opened the circuit breaker to the utility. This electrically isolated the generator from the grid.

Discussion: The machine was safely secured and sustained relatively minor gamage during the safety-system-controllea shutdown. The torque plate, which is mounted on the rotor hub assembly, contained the 22 broken ends of the studs within helicoil inserts. The remaining portions of the broken studs were recovered from the lower portion of the beoplate. The outer sleeve of the gear coupling was dallaged ouring the shutaown and will require replacement. It rapped the pitch-rod adjusting mechanisin ouring the shutdown. These adjusting mechanisms and the "uniball" end fittings must be replaced. The instrumentation and the power wiring bunale and conouit within the low-speed shaft were severed when the cuupling and low-speed shaft separated from the rotor hub and must be replaced.

Figure 37 illustrates a section view of the hub-shaft interface and locates the studs that failea. During assembly, personnel access to the back side of the hub torque plate was limited. This necessitated the blind connection. Figure 38 illustrates the stud-helicoil installation in the coupiing joint between the rotor hub torque plate and the low-speed shaft. self-locking stainless-steel helicoil inserts were usea to increase the 


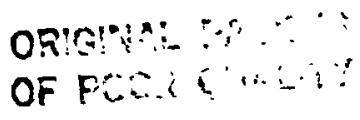

thread strength in the mild steel torque plate. The stuos pass through clearance-oversized holes needed for helicoil installation in the torque plate before engaging the helicoil insert.

The rotor-hub-torque-plate-to-coupling interface was designed as a conventional friction joint, with the fastenliss studs providing the preloading to a joint capacity of $885000 \mathrm{ft}-1 \mathrm{~b}$. The drive train has a rated torque capacity of $442000 \mathrm{ft}-1 \mathrm{~b}$, which yields a joint safety factor of 1.95. The drive train slip clutch is adjusted to slip at a setting of $829000 \mathrm{ft}-\mathrm{lb}$, or 93 percent of the joint rating.

metallurgical analysis of the failed studs revealea that high strain, predominantly low-cycle bending fatigue, was the cause of the stud fractures at the helicoil end. The stud material was found by metallurgical analysis to be of excellent quality and free of any defects. After the failure, examination of engineering log books indicated that the stuos were not properly preloaded. It is believed that this would result in a joint torque capacity of $683000 \mathrm{ft}-16$, or only 77 percent of its original design value. The stud geometry and spacing in the oversized torque plate and gear coupling holes would allow a relative rotition of $1^{\circ}$ between the torque plate and the gear coupling. Torque loading of the arive train forced relative rotation, which in turn caused the studs to fail by bending fatigue. A second major contributing factor was that the slip clutch malfunctioned on several occasions before it was discovered to be operating improperly. A thiru contributing factor was occasional torque loadings in excess of the design values, incluaing both peak and cyclic torque overloads. This failure can be attributeo principally to improperly installed studs and a malfunctioning slip clutch, which was installed as an overtorque protection. device.

Assessment: The failea joint has been fully revieweo ano analyzed ano a suitable repair method identified. The orive train damage can be repaired for the most part in the nacelle with only the low-speea shaft and pitchchange mechanism being removed. The rotor hub torque plate rework will require precision machining, and several sources that can provide this type of service have been ioent if ied.

specific recomnendations: Basic friction-torque joints are desirable in future wind turbine applications because they cost less than other conventional designs. Also, some drive train designs may have no other alternative than to use friction-torque joints. Vesigners in designing this type of joint should consider providing a friction-torque capability for all specified loads, with a safety factor of 2.5 as a minimum. In addition, the designer should assume that the joint will slip near limit loads and that the fasteners will be carrying the torque load in snear. Clearances arounu fasteners should be minimized so that the fasteners will be more uniformly loaued. Vesigners are urged to be conservative in selecting a friction coefficient for this type of joint. Through-joint fasteners that are positively locked are recommended. Lastly, the fastener tensioning technique lliust be verifiec iy testing and also verified at installation by proper inspection. Usir a slip clutch as a overtorque safety uevice in wina turbines is consider acceptable. Particular attention must be paid to the application installation, and understanaing of all tacets of its operation and maintenance. Vesigners must obtain enough detailea information from the slip clutch manufacturers to fully understand the operation and limits especially if the unit is not a shelf item or is a shelf item that has been modified. 


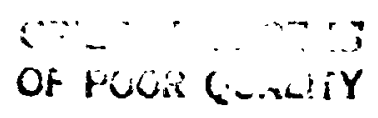

\section{Public Reaction and Acceptance}

Over the past 2 years, public reaction to the Mod-1 wina Turbine program has been favorable. This includes most local people who live in and around Boone near the turbine site. In that regional area of Morth Carolina and over the rest of the country, people were supportive although not as interested in the project as the Boone residents. Nationally, the Mod-l program was recognized as the first operational megawatt-size wind turbine in the world.

Discus:ion: There have been many articles in the Morth Carulina and Boone papers reporting on the various phases of the Mod-l program over the past 2 years. Uccasionally, rational publications such as Time Magazine, the Wall Street Journal, and Aviation Week Space Technology have had articles on the Mod-1. Trade journals including 1980 Generation Planbook and Electrical World have published material describing the Mod-l wind turbine. Mewspapers outside Morth Carolina such as The New York Times, Washington Post, Clevelana Plain Vealer, and Philadelphia Inquirer and others have published articles about the project. The North Carolina television scations have also reported numerous times on the mod-l program.

Various management personnel from the Blue Ridge Electric Membership corp. have given an average of over 100 talks per year around the state of North Carolina to various civic, religious, and public organizations during the first 2 years of the project. The BREMC management has reported that the groups they have talked to as well as the general boone residents have been very supportive of wind power as a form of generating electric energy. The academic conmunity from Appalachian State University, a local college, has conducted energy seminars, including wind energy reviews, and are conducting their own wind energy project, which consists of operating a small horizontal-axis wina turbine.

The Mod-l site is a continual attraction to visitors to the ioone area, many of whom come from the southeastern part of the uniteo States. Approximately 4000 informational brochures on the Mod-1 have been passed out to site visitors per year during the normal working hours by maintenance personnel. Uuring the fall of the year, when the leaves are changing color in the local mountains, 1500 visitors have visited the site on several successive weekends. This caused traffic problems on the access road, and local off-duty police were hired to control the traffic flow. Many foreign visitors from South America, Asia, and Europe as well as members of the United States Government and inaustry leaders have visited the site. In fact, the large number of foreign and domestic VIP groups has occasionally disrupted the ino-l program schedule. School classes, youth groups, professional organizations, etc., are continually scheduling visits througn the local BREMC Vistrict Manayer.

Assessment: The public reaction to the Mod-1 Wind Turbine program has been demonstrated continually by the number of visitors to the site. The people have clearly expressed to BREMC and site personnel their desire for pollution-free electricity that is not depenoent on foreign-produced oil. The local people have expressed their desire to see the wind turbine operating more of the time. The wind velocity is highest during the evening and early morning hours; therefore they have not observed the wind turbine during much of the operating time. In addition, configuring for testing causes periods of time when the wind turbine cannot be operated. In the opinion of the personnel involved with the wind turbine from OREMC, NASA, and the General Electric Co., the public who have visited the site and the 


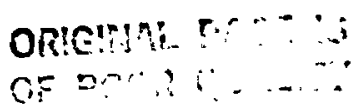

lccal Boone residents are definitely in favor of producing electric power by wind turbines generators.

\section{CONTRIBUTIOHS TO WINO TURBINE TECHMOLOGY}

Since the Mod-1 wind turbine was the first modern megawatt-size machine that had as its purpose research and development, it has made a number of major contributions to wind turbine technology. These contributions resulted both from deliberate investigative efforts as well as from unexpected problems that occur during any "first of a kind" endeavor. The important technology developments that can be attributed to the Mod-1 program include innovative low-cost wind turbine design concepts and metal and composite blade fabrication techniques. The Mod-l was the first remote, unattended 2-MW wind turbine to synchronize, to generate power to a public utility system, and to be controlled by a utility dispatcher. Computer codes were verified for dynamic and loads analysis, performance prediction, and electrical stability analysis. These will be useful for future generation designs of megawatt-size systems. Environmental impact issues, such as sound generation and television interference, were experienced and evaluated and solutions for wind turbines were identified. And finally, a host of "lessons learned," including the importance of optimizing an installation site to wind turbine characteristics, have been reported in the literiture for the benef it of the industry.

\section{Innovative Design Concepts}

Just after the completion of the Mod-1 design, a Mod-1A configuration was designed and was reported to the wind turbine industry at a NASA workshop in March 1979. The Mod-1A synthesized the innovative concepts that were a byproduct of the Mod-l design experience. These low-cost concepts identified on the Mod-1A, which were beyond the scope of the Mod-1 specification, have been incorporated in second- and later-generation wind turbines. These innovations are a soft tower, partial span control, a teetered hub, and an upwind rotor. The use of these corcepts, along with others, has resulted in cost-effective wind turbines that are the reystone of the emerging commercial market.

\section{Blade Manufacturing Technology}

The manufacturing of the Mod-1 rotor blades, modern industry's initial attempt to construct a 100-ft-long blade, established the fabrication technology for welding and stress relief of steel blades for the wind turbire industry. The Mod-1 blades have performed successfully for over three quarters of a million cycles, and "know how" from these blades has been incorporated in second-generation welded steel blades. Also two composite fiberglass rotor blades designed specifically for the Mod-1 have recently been manufactured, further establishing the transverse filament tape (TFT) manufacturing process. One-hundred-foot blades once regarded as a challenge in the 1970's will be commonplace in the 1980's primarily as a result of the knowledge gained by the Mod-l design and manufacturing experience. 


$$
\begin{aligned}
& \text { ORLE.: } \\
& \text { OF Fut: }
\end{aligned}
$$

\section{Power Generation Feasibility}

In the area of performance, the Mod-1 demonstrated that a multimegawatt wind turbine could be successfully synchronized with a utility grid ano generate stable electric power that meets utility-quality standards. The Mod-1 also demonstratea that an unattended wind turbine could be operated remotely in conjunction with a utility system by a utility dispatcher in a fully automatic more. Although power level varied significantly with wind speed and direction fluctuations, voltage flicker was well with in utility standaros. Transients associated with initial synchronization and wind turbine shutdown exhibited a stable, acceptable behavior.

\section{Environmertal Impact}

Perhaps the most significant contribution to wind turbine technology resulted from the environmental effect of the Mod-? on the boone, N.C., cormunity. In the fall of 1979, shortly after dedication, unanticipated complaints from local resiaents about objectionable sound and television interference caused by the wind turbine were received by BREMC, the local utility. As a result, extensive efforts were conoucted to characterize and solve sound and television interference problems at boone and to establish standards. The specific knowledge developed on the pnenomerion was then incorporated into the second-generation wino turbines.

In regard to sound, extensive measurements were mace in the immediate vicinity of the wind turbine ano at remote residential locations, intermittently and continuously, and during daylight and evening hours at various weather conditions. These measurements were made at various wind turbine rotational speeds, on line and off. The most important favorable effect of the Hod-1 experience at Boone was an acute awareness throughout the inaustry of the noise generation problen. A solution to the boone prodem was arrived at by reducing the rotor speed. In addition, this unexpected sitespecific environmental concern provided tne inpetus to characterize wino turtine sound generation, to develop predictive computer codes, and to establish sound standards. The body of knowledge that evolved from the mod-l experience is being incorporated into future-generation designs and into utility site-selection criteria.

A parallel story about television interference unfolded in much the same manner as that for wind-turbine-generateo sound. Although not tutally unexpected because of prior experience at Mod-OA sites, television interference caused complaints within a 1.5 -mile radius because of the ierrain ano consequentiy restricted wing turbine operation. An extensive ineasurement program was conoucted that evaluatea basic signal strength ano interference characteristics. The results of the test program lea to the evaluation or three tentative solutions: high-gain residential antennas, cable television, ano VHF-to-UHF rebroadcast translators. II the interim, however, the television interference problem was eliminated by restricting the turbine operation to other than prine television time. Thus far Moc-l has contribuced to the understanding and identification of solutions to this critical environnertal problen that will affect future wina turoine siting decisions. 


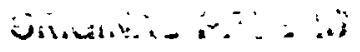

OF PCOA: $, \ldots:$ :

\section{CONCLUSIONS}

\section{Power Generation on UL lility Grid}

The wind turbine has generated electric energy witnin utility standaras in a stable and well-controllea manner. At $35 \mathrm{rpm}$ transient wind conditions have had no adverse effect on the power generated or the machine. At $23 \mathrm{rpm}$ the power generated was still within utility standards, but the drive train was responding to its fundamental frequency.

\section{Controls and Unattended Operation}

The control syste, initially presented a succession of minor problems and they were eventually solved. After the program acceptance tests the control system performed flawlessly as designed. The wind turbine was operated successfully in all modes, incluoing manual operation, autonatic oneration, unattended operation, and unattended remote control from the blue Ridge Electric membership Corp. (HREMC) dispatchers office in Lenoir, W.C. In addition, the versatility of the control system allowed testing in various unconventional machine configurations during the Mod-l test program.

\section{Television Interference}

Cable television and rebroadcast via translators both provice excellent solutions to el iminate television interference causea by wind turbines. Many areas of the country already have these systems installed. because of the recent strong interest by the business community in providing these communications systems, cable television and translator systems are being installed at a rapid rate throughout the country. This will be a definite advantage to the users of wina turbines.

\section{Wina-Turbine-Generated Sound}

As a result of the sound test program conducted on the mod-1, the sound emitted by wind turbines is now defined, understood, and predictable. In addition, acceptable sound level requirements for wind turbines are being established for designers' use. The meteorological and topological effects on sound propagation ana focusing will be important criteria in wind turbine site selections.

\section{Drive Train Uynamics}

When the Moo-1 was operated as originally designed at $35 \mathrm{rpm}$, the machine ran well, was compatible with the utility, and was dynamically very stable. When the mod-1 was test configured at $23 \mathrm{rom}$ to recuce the sound enitted, the machine responded to its fundamental frequency is nigh turbulent winds, but it was compatible with the utility and was cyramically stable. A solution to the 23-rpm arive train fundamental frequency problem would be a more active blade pitch control system. This would increase the arive train damping and thus would permit the drive train to operate with less excitation of the first torsional moce in turbulent winds. 


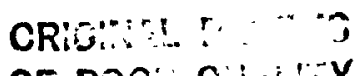

Of PoOri Quniniry

\section{Public Reaction and Acceptance}

The NASA, BREMC, and General Electric personnel involved with the Mod-1 program believe that the members of the public whom they have talked with at the site as well as the local resigents around Bcone have a very positive attitude toward using wind ti:bines to generate electric energy. The iarge number of visitors and groups from foreign countries and the United States visiting the Mod-l site in this remote micuniain community attests to the popularity of this method of energy conversion.

\section{Contributions to Wind Turbine Technology}

The Mod-l program ras made substantial contributions to the aevelopinent of wind turbine technology. GE, through the experience gained during the design phase of the program, developea many low-cost design concepts for the benefit of the wind turbine inaustry. Metal and composite blade manufacturing technoiogy was also developed. The Mud-l first demonstrated that a megawatt-size wina turbine could be operated in an unattenaeo, fully automatic mode and generate utility-quality power into a public utility system. Analytical computer codes for predicting wind turbine dynamic and loads analysis were verified from Mod-1 data. A significant contribution to the wind turbine industry was the discovery that the MoG-l had an environmental impact on the community.

\section{Project Ubjectives}

The following specific Mod-1 project objectives, which were a part of the Federal Wind Energy program, have all been achieved:

(1) To provide operational and performance data for a megawatt-size wind turbine

(2) To demonstrute unattended, fail-safe operation

(3) To involve a utility as user and operator

(4) To identify maintenance requirements

(5) Tn involve industry in desigh, fabrication, and installation of the wind turbine

(6: To identify component and subsystem modifications to reduce cost, improve reliability, and increase performance

(7) To assess public reaction to and acceptance of large wing turbines

(8) To cemonstrate compatibility with utiiity requirements

The following natiorially recognized experts and tho ir organizations have made major contributions to portions of the proyram. They aojusteu their busy schedules to be availabie when needed for conaucting field tests, analyzing results, developing analytical prediction techniques, writing reports, and attending meetings: 
ORIG:In: PRGE IS

DF POOK QUALITY

- O. L. Sengupta, T. B. A. Senicr, J. E. Ferris of the University of Michigan

- J. F. X. Brome of John F. X. Brome Associates

- R. J. Hells of General Electric Corporate Research and Development

- General Electric Corporate Research and Development Staff

- N. Kelley of Solar Energy Research Institute

- G. C. Green and D. G. Stephens of MASA Langley Research Center

The two Mod- 1 blade contractors and their project managers, J. Van Bronkhorst, Boeing Engineering and Construction, and W. Batesole, Kaman Aerospace Corp., also made importar. contributions to the program.

J. Brown of GE and $T$. Miller of BREMC were at the site during the machine's assembly and continued their outstanding support during the operational period.

\section{REFERENCES}

1. Puthoff, R. L.; Collins, J. L.; and wolf, R. A.: Installation and Checkout of the DOE/NASA Mod-1 2000-kW Wind Turoine Generator, DOE/NASA/1010-80/6, NASA TM-81444, 1980.

2. Mod-1 Wind Turbine Generator Failure Modes and Effects Ana iys is. (DOE/NASA/0058-79/1, General Electric Co.; NASA Contract NAS3-20058.) NASA. $Z R-15494,1979$.

3. Executive Summary: Mod-1 Wind Turbine Generator Analys is and Design Report. (DOE/NASA/0058-79/3, General Electric Co.; NASA Contract NAS3-20058.) NASA C.R-159497, 1979.

4. Mod-1 Wind Turbine Generator Analys is and Design Report, Volume 1. (DOE/NASA/0058-79/2-Vol. 1, General Electric Co.; NASA Contract NAS3-20058.) NASA CR-159495, 1979.

5. Batesole, W. R.: Fiberglass Composite Blades for the 2 MW Mod-1 Wind Turbine Generator. Presented at DOE/NASA Workshop on Large HorizontalAx is Wind Turbines (Cleveland, Ohio), Juls 28-30, 1981.

6. Sengupta, D. L.; Senior, T. B. A.; and Ferris, J. E.: Measurements of Interferer.'e to Television Reception Caused by the Mod-1 WT at Boone, N.C. Tech. Rep. No. 1, Univ. of Michigan, 018291-1-T, Jann. 1981.

7. Senior, T. B. A.; and Sengupta, D. L.: Large Wind Turbine Siting Handbock: Television Interferance Assessment. Tech. Rep. No. 4, Univ. of Michigan, 014438-4-T, Rpr. 1981.

8. Browne, J. F. X.: Television Translator Proje:i, Jone, N.C. Final Report, John F. X. Browne and Assoc., Mar, ig8l. 
9. Wells, R. J.: Mod-l Wind Turbine Generator Prel iminary Moise Evaluation. General Electric Co., hay 1, 1980.

10. Wells, R. J.: Mod-l Wind Turbine Generator Statistical Moise Studies. 81-505-4214, General Electric Co., Mar. 1981.

11. Thanson, D. W.; and Roth, S. D.: Enchancement of Far Field Sound Levels by Refractive Focusing. Wind Turbine Dynamics, MASA CP-2185, 1981, pp. 397-400.

12. Robbins, H. H.; Thomas, R. L.; and Baldwin, D. H.: Large Wind Turbines - A Utitity Option for the Generation of Electricity, UUE/MASA/23139-1, MASA TM-81502, 1980.

13. Spera, D. A.; and Janetzke, D. C.: Performance ano Load vaca from ine MOd-OA and Mod-1 Wind Iurbine Generators. Presented at WUE/MASA Hork-shop on Large Horizontal-Axis tiind Turbines (Clevelana, Uhio), July 29-30, 1981.

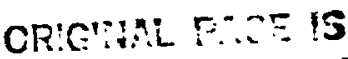

OF PUi: \&udatr 


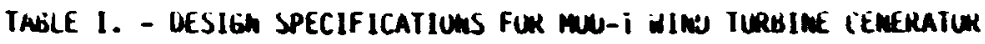

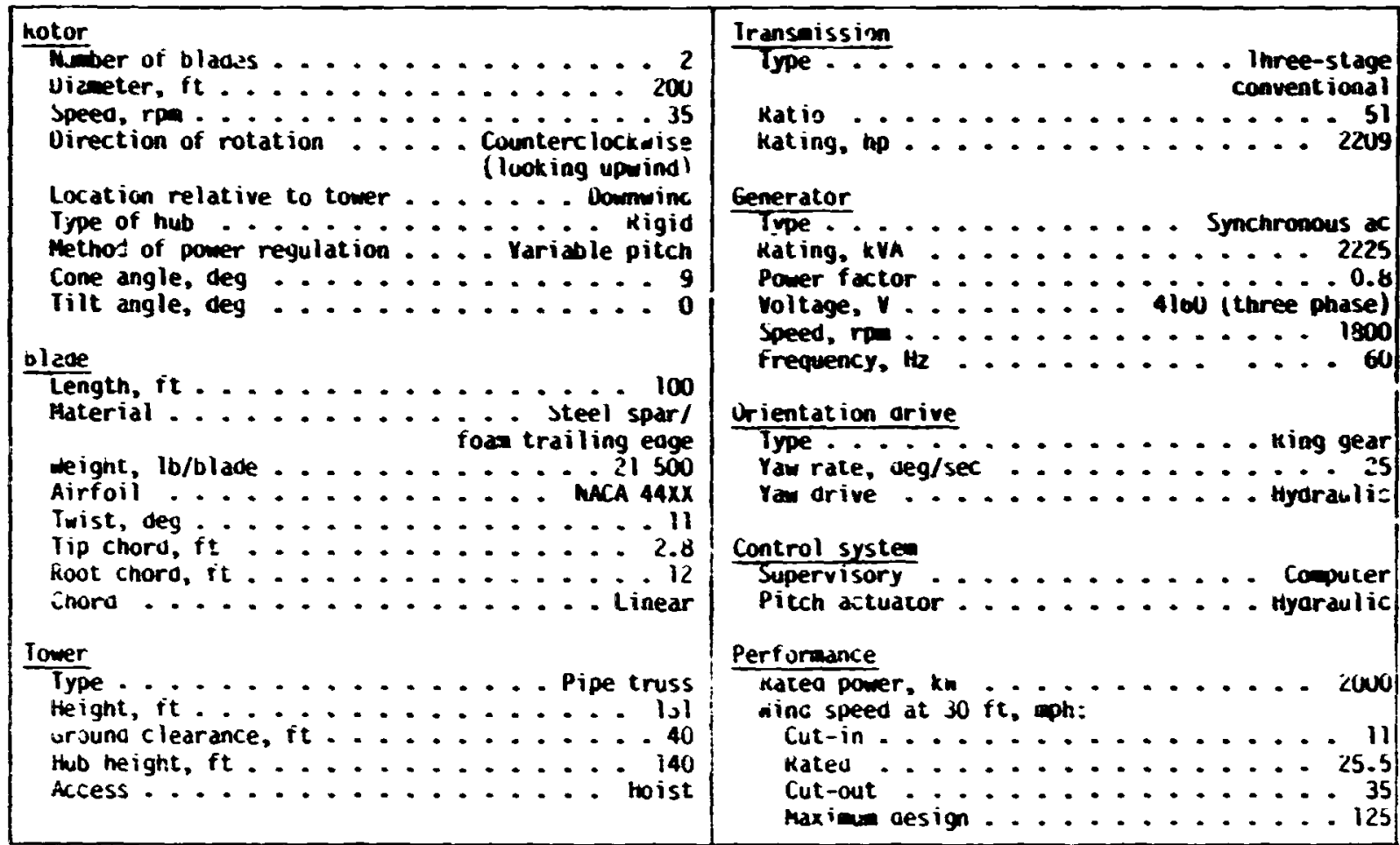

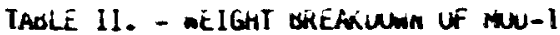

WIMU TIRBIKE GEMERATUK

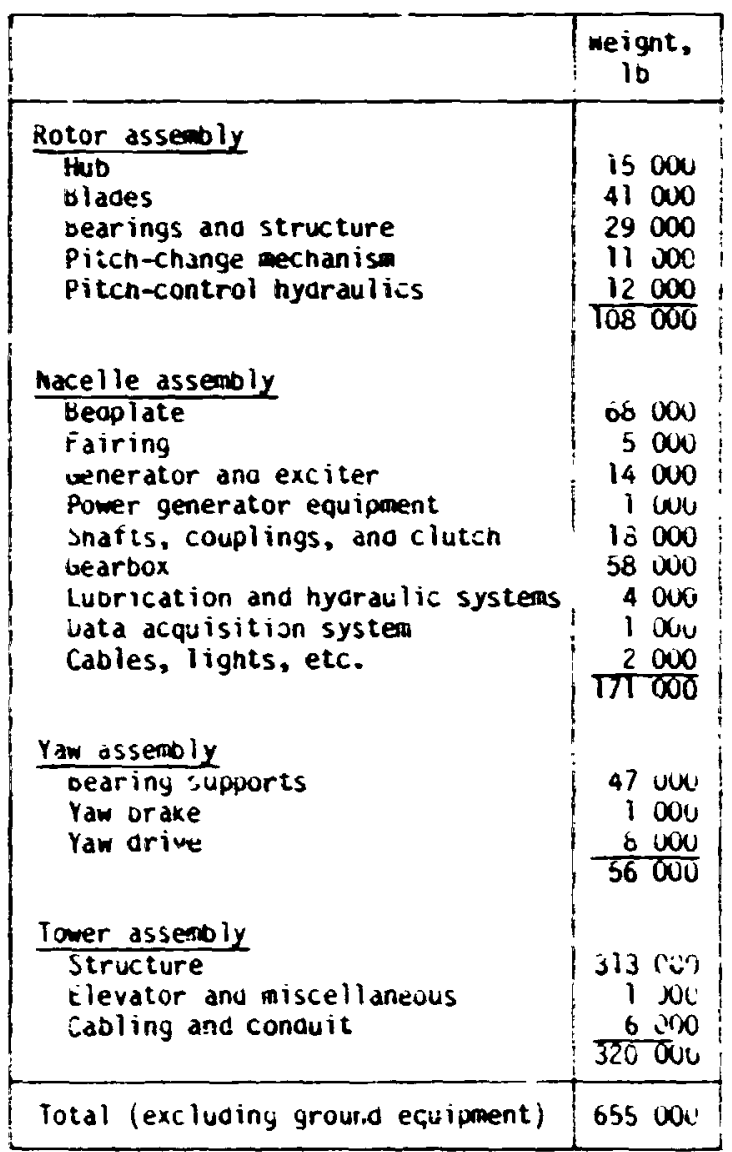


TARE 111. - MOD-1A OQJECTIVES

\begin{tabular}{|c|c|c|}
\hline Objective & nod-1 & hod-1A \\
\hline 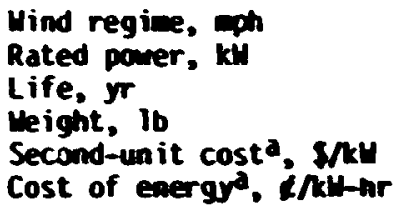 & $\begin{array}{r}18 \\
2000 \\
30 \\
655000 \\
2900 \\
18\end{array}$ & $\begin{array}{r}18 \\
2000 \\
30 \\
400000 \\
1000 \\
5\end{array}$ \\
\hline
\end{tabular}

a1978 dollars.

TABLE IV. - MOO-1 manne fUnctions

\begin{tabular}{|c|c|}
\hline Function & $\begin{array}{l}\text { Additional restrictive } \\
\text { conditions }\end{array}$ \\
\hline \multirow{4}{*}{ 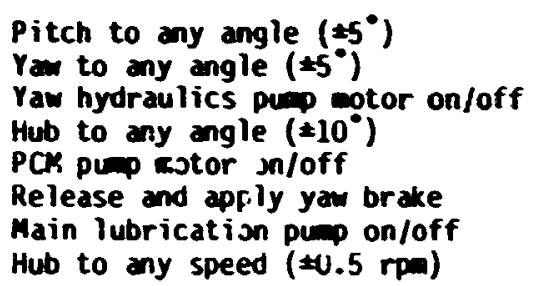 } & $\begin{array}{l}\text { Hind speeda, } 15 \text { ph } \\
\text { wind speedd, } 35 \text { ph }\end{array}$ \\
\hline & wind speed a, 25 ph \\
\hline & wind speed ${ }^{\mathrm{a}}, 25 \mathrm{ph}$ \\
\hline & Break-away wind speed ${ }^{2}, 25 \mathrm{mph}$ \\
\hline
\end{tabular}

Wind speed measured at hub height. 
TABLE V. - MOD-l CONTROL SYSTEM FUMCTIONS

\begin{tabular}{|c|c|}
\hline Function & Desc-iption \\
\hline $\begin{array}{l}\text { Monitor enable } \\
\text { Initialization } \\
\text { Site enable } \\
\text { Antistall } \\
\text { Orerstress } \\
\text { Ya correct } \\
\text { Pitch rap } \\
\text { Speed ramp } \\
\text { Rate symchronizaticn } \\
\text { Voltage synchronization } \\
\text { Angle synchronization } \\
\text { Power rap } \\
\text { Shutdoim } \\
\text { Power peaking }\end{array}$ & 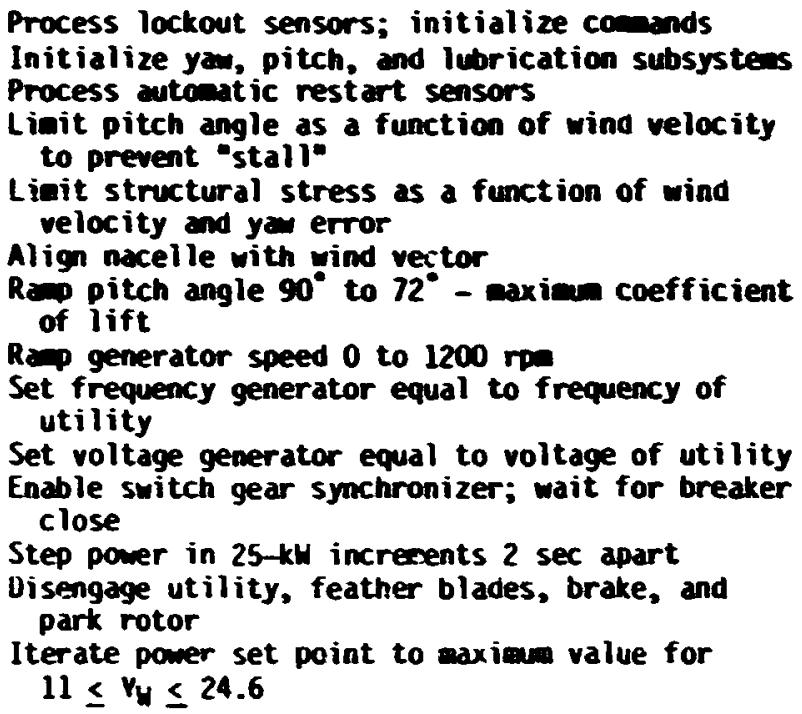 \\
\hline
\end{tabular}

TABLE VI. - MOD-1 PITCH-CONTROL MOOES OF OFERATION

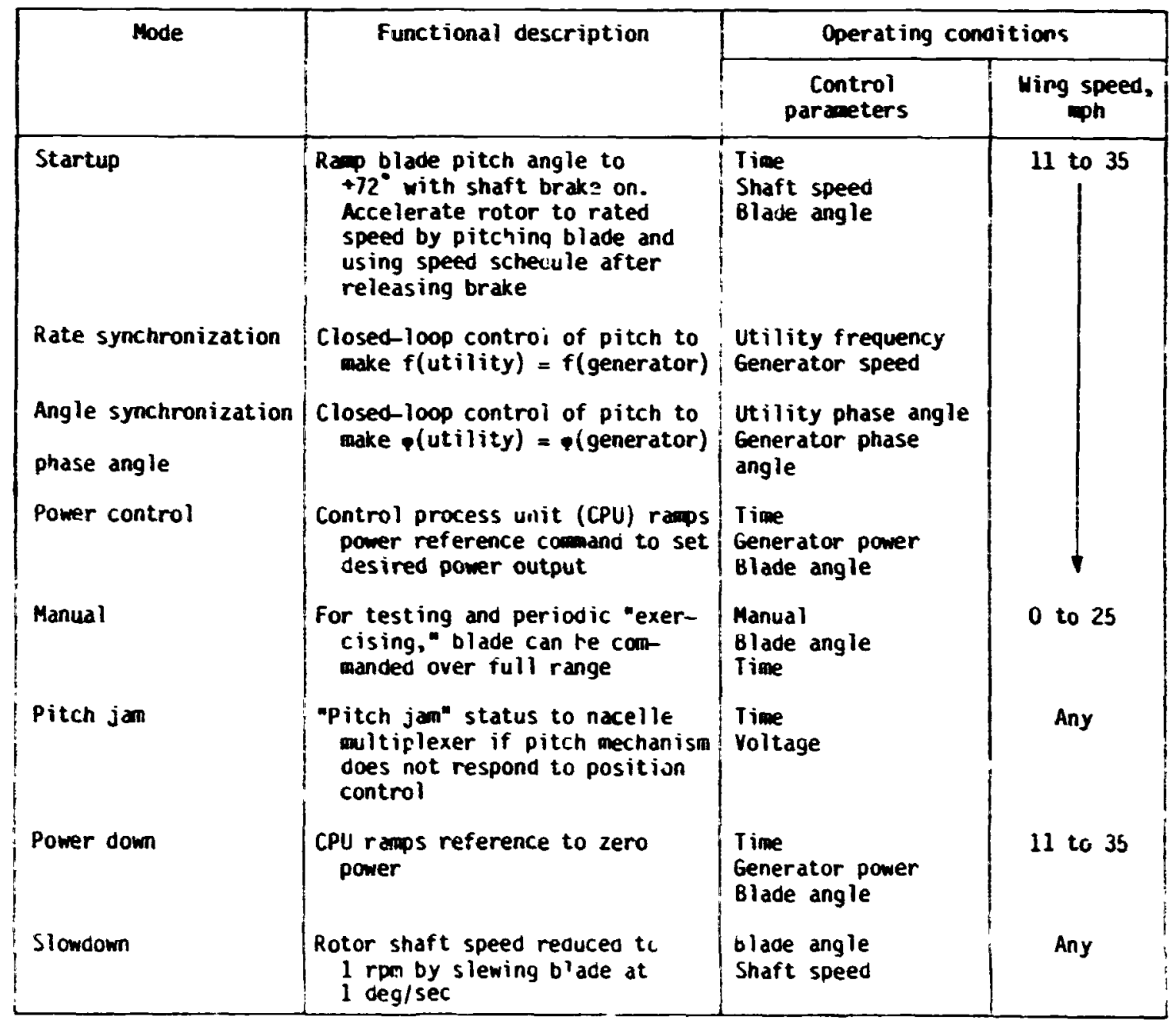


TABLE VII. - YAH COMTRO

\begin{tabular}{|c|c|c|c|}
\hline Wind speed, & Drive & Brake & wotes \\
\hline $\begin{array}{l}0 \text { to cut-in } \\
\text { Cut-in to cut-out } \\
\text { Nowe cut-out } \\
0 \text { to rated }\end{array}$ & $\begin{array}{l}\text { Orf" } \\
\text { Corrects for yow error } \\
\text { of } 5 \text { for } 5 \text { win } \\
\text { coff" } \\
\text { mavial - to any angle }\end{array}$ & $\begin{array}{l}\text { On" } \\
\text { "Off" wen not rotating; } \\
\text { "on" if rpo above } 8 \text { at } \\
\text { lower pressure } \\
\text { on" } \\
\text { nanual }\end{array}$ & $\begin{array}{l}\text { no operation } \\
1 / 4 \text { deg/sec } \\
\text { Shutdom } \\
\text { for test }\end{array}$ \\
\hline
\end{tabular}

TABLE VIII. - SHUTOONA LOGIC

\begin{tabular}{|c|c|c|}
\hline Type of shutdam & Contiol system functions & Criteria for shutcom \\
\hline Mormal & $\begin{array}{l}\text { Yaw off if failure } \\
\text { Power down (pitch changc) } \\
\text { breaker open } \\
\text { Slowdoin (speed ramp) } \\
\text { Rotor stop } \\
\text { Apply parking brake }\end{array}$ & $\begin{array}{l}\text { Manual comand } \\
\text { Dispatcher comand } \\
\text { Wind speed arops below } 11 \text { aph } \\
\text { User subsystem failure } \\
\text { wind speed and yaw error out of band } \\
\text { Temperaturas out of band } \\
\text { Average wind speed above } 35 \text { wh } \\
\text { Emergency pitch hyoraulic pressure low }\end{array}$ \\
\hline Emergency & $\begin{array}{l}\text { Yaw off if failure } \\
\text { Pitch emergency feather } \\
\text { Breaker open } \\
\text { Rotor stcp } \\
\text { Apply parking brake }\end{array}$ & $\begin{array}{l}\text { Frequency out of band } \\
\text { Shaft speed too high } \\
\text { Main breaker open wile ir, generator } \\
\text { Utility voltage dip below limit } \\
\text { Wino speed and yaw en or out of band } \\
\text { Any vibration above limit } \\
\text { Data iink ancmaly }\end{array}$ \\
\hline Utility outage & $\begin{array}{l}\text { Emergency featner } \\
\text { Yaw notor of } r \\
\text { Brake on sha't brake off }\end{array}$ & utility vo!tage drops out \\
\hline Pitch jam & $\begin{array}{l}\text { Emergency feather } \\
\text { Yaw } 90^{\circ} \text { to wind and track }\end{array}$ & blade will not respond \\
\hline
\end{tabular}

table IX. - television chanmels availadie in boOne

\begin{tabular}{|c|c|c|c|c|c|c|c|}
\hline \multirow[t]{2}{*}{ Channel } & \multirow[t]{2}{*}{ Station location } & \multirow{2}{*}{$\begin{array}{l}\text { Metwork } \\
\text { affil- } \\
\text { iation }\end{array}$} & \multirow{2}{*}{$\begin{array}{l}\text { Effective } \\
\text { radiated } \\
\text { visual } \\
\text { power, } \\
\text { kW }\end{array}$} & \multicolumn{2}{|c|}{ Antenna location } & \multirow{2}{*}{$\begin{array}{c}\text { Oistance } \\
\text { from wind } \\
\text { turbine, } \\
\text { km }\end{array}$} & \multirow{2}{*}{$\begin{array}{l}\text { Direction } \\
\text { to trans- } \\
\text { mitter, } \\
\text { deg from }\end{array}$} \\
\hline & & & & Latitude & Longitude & & \\
\hline $\begin{array}{l}2(a) \\
2(b) \\
3 \\
5 \\
7 \\
8 \\
9 \\
11 \\
12\end{array}$ & $\begin{array}{l}\text { Sneedvilie, Tenn. } \\
\text { Gree-sboro, N.C. } \\
\text { Charlotte, N.C. } \\
\text { Bristol, Va. } \\
\text { Spartanburg, S.C. } \\
\text { High Point, N.C. } \\
\text { Charlotte, N.C. } \\
\text { Johnson City, Tenn. } \\
\text { Winston-Salem, N.C. }\end{array}$ & $\begin{array}{l}\text { ABC } \\
\text { CBS } \\
\text { CBS } \\
\text { MBC } \\
\text { CBS } \\
\text { None } \\
\text { ABC } \\
\text { CBS } \\
\text { NBC }\end{array}$ & $\begin{array}{l}100 \\
100 \\
100 \\
85.1 \\
294.1 \\
316 \\
316 \\
245 \\
316\end{array}$ & $\begin{array}{l}36^{\circ} 22^{\prime} 52^{\prime \prime} \\
35^{\circ} 522^{\prime} 13^{\prime \prime} \\
35^{\circ} 17^{\prime} 54^{\prime \prime} \\
36^{\circ} 20^{\prime} 57^{\prime \prime} \\
35^{\circ} 10^{\prime} 26^{\prime \prime} \\
35^{\circ} 48^{\prime} 47^{\prime \prime} \\
35^{\circ} 15^{\prime} 41^{\prime \prime} \\
36^{\circ} 25^{\prime} 55^{\prime \prime} \\
36^{\circ} 22^{\prime} 31^{\prime \prime}\end{array}$ & $\begin{array}{l}83^{\circ} 10^{\circ} 48^{\prime \prime} \\
79^{\circ} 50^{\prime} 25^{\prime \prime} \\
81^{\circ} 66^{\prime} 53^{\prime \prime} \\
82^{\circ} 6^{\prime} 31^{\prime \prime} \\
82^{\circ} 17^{\prime} 26^{\prime \prime} \\
79^{\circ} 50^{\circ} 36^{\prime \prime} \\
80^{\circ} 43^{\prime} 38^{\prime \prime} \\
82^{\circ} 8^{\prime} 15^{\prime \prime} \\
80^{\circ} 22^{\prime} 27^{\prime \prime}\end{array}$ & $\begin{array}{r}134 \\
170 \\
116 \\
40 \\
130 \\
171 \\
138 \\
47 \\
118 \\
\end{array}$ & $\begin{array}{r}278 \\
103 \\
154 \\
302 \\
205 \\
105 \\
141 \\
299 \\
82\end{array}$ \\
\hline
\end{tabular}




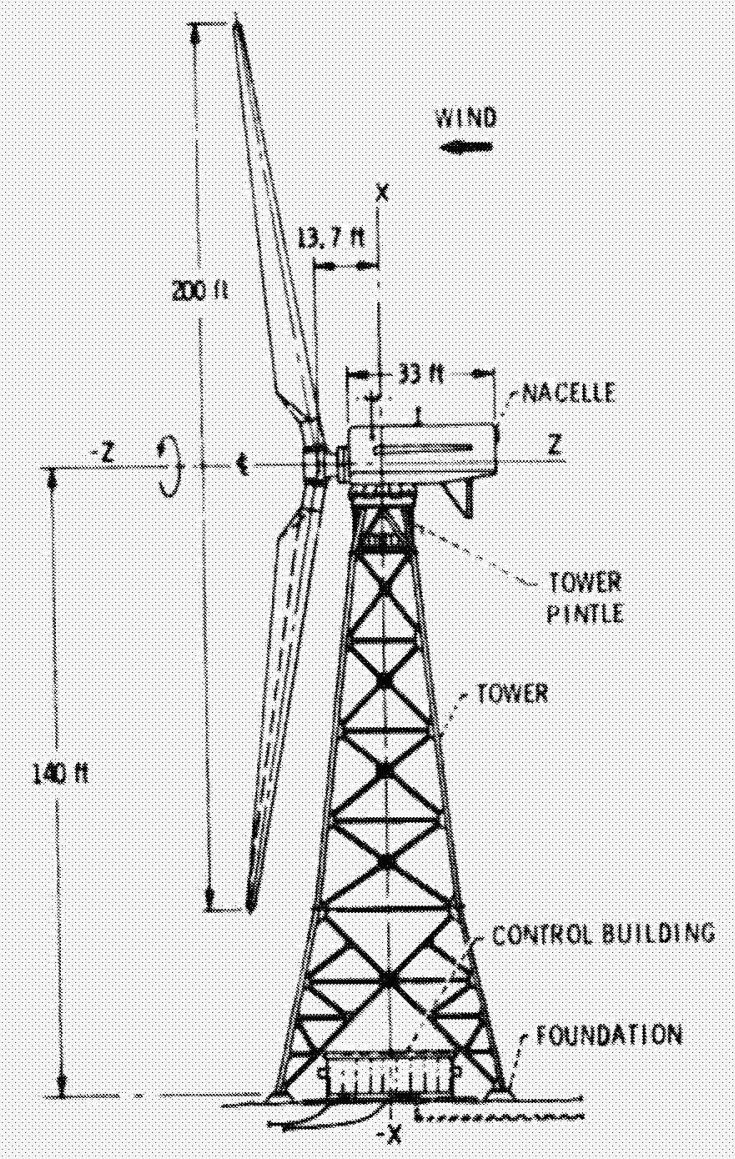

fiqure 1, - Mod-12-MW wind turtine.

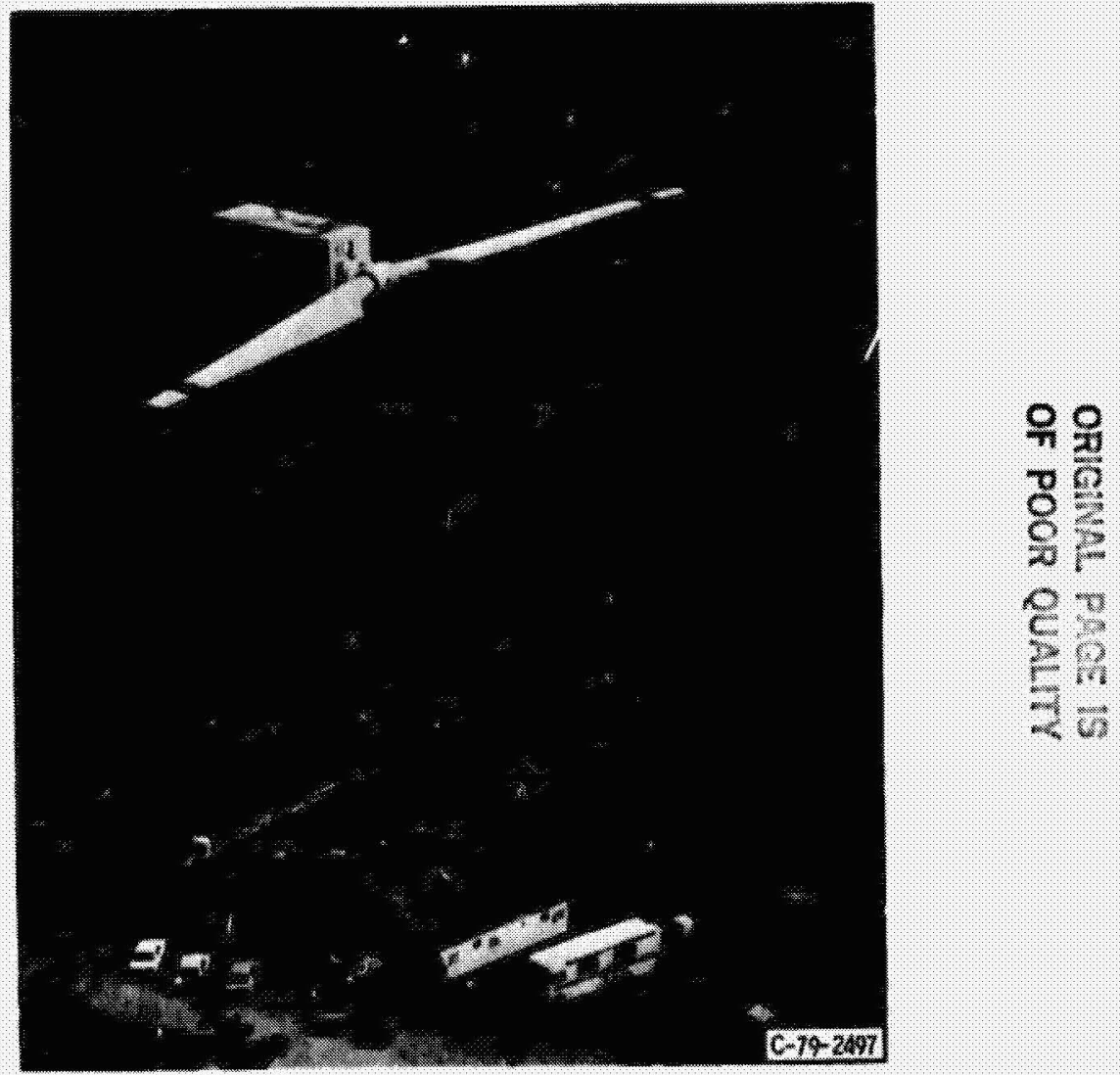

Fiqure 2. - DoL-NASA 2000-kW experimental wind turbine, Howard Knob, Boone, N, C. 


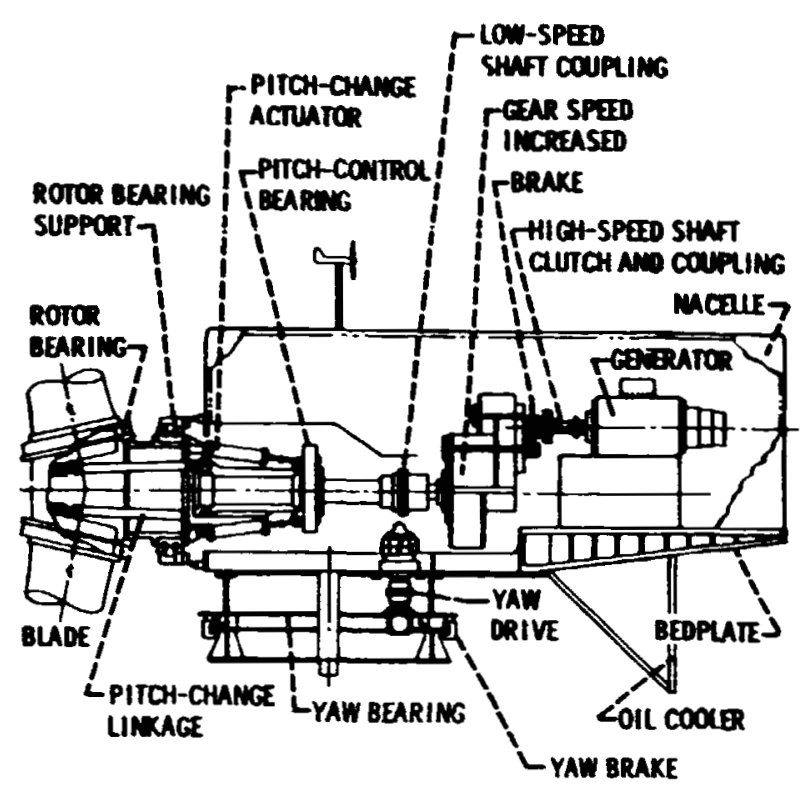

cris:?

OF pos a in:

Figure 3. - Schematic diagram of Mot- I wind turtine assembly.

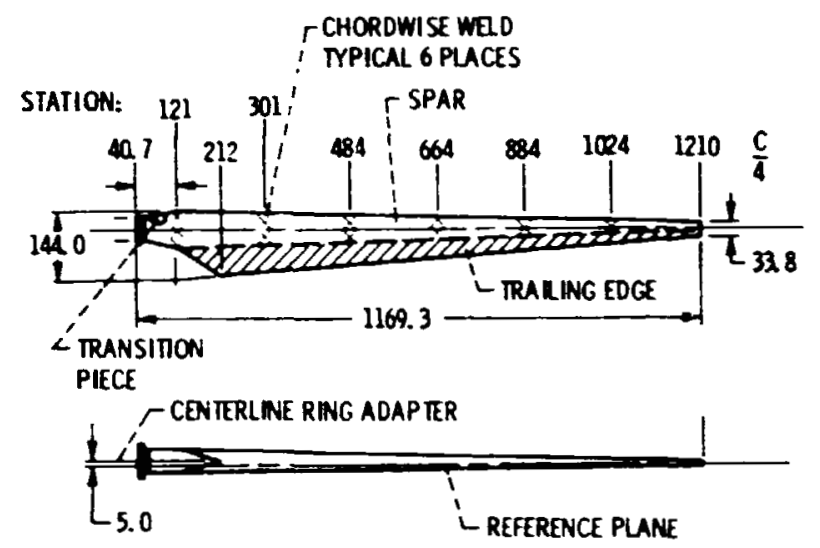

(a) Blade geometry. Dimensions are in inches.

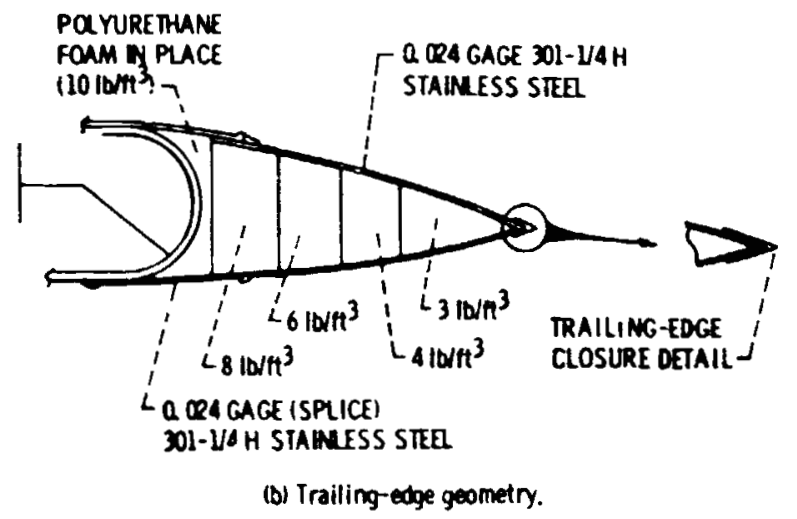

Figure 4 - Biade and trailing-edge geometry. 

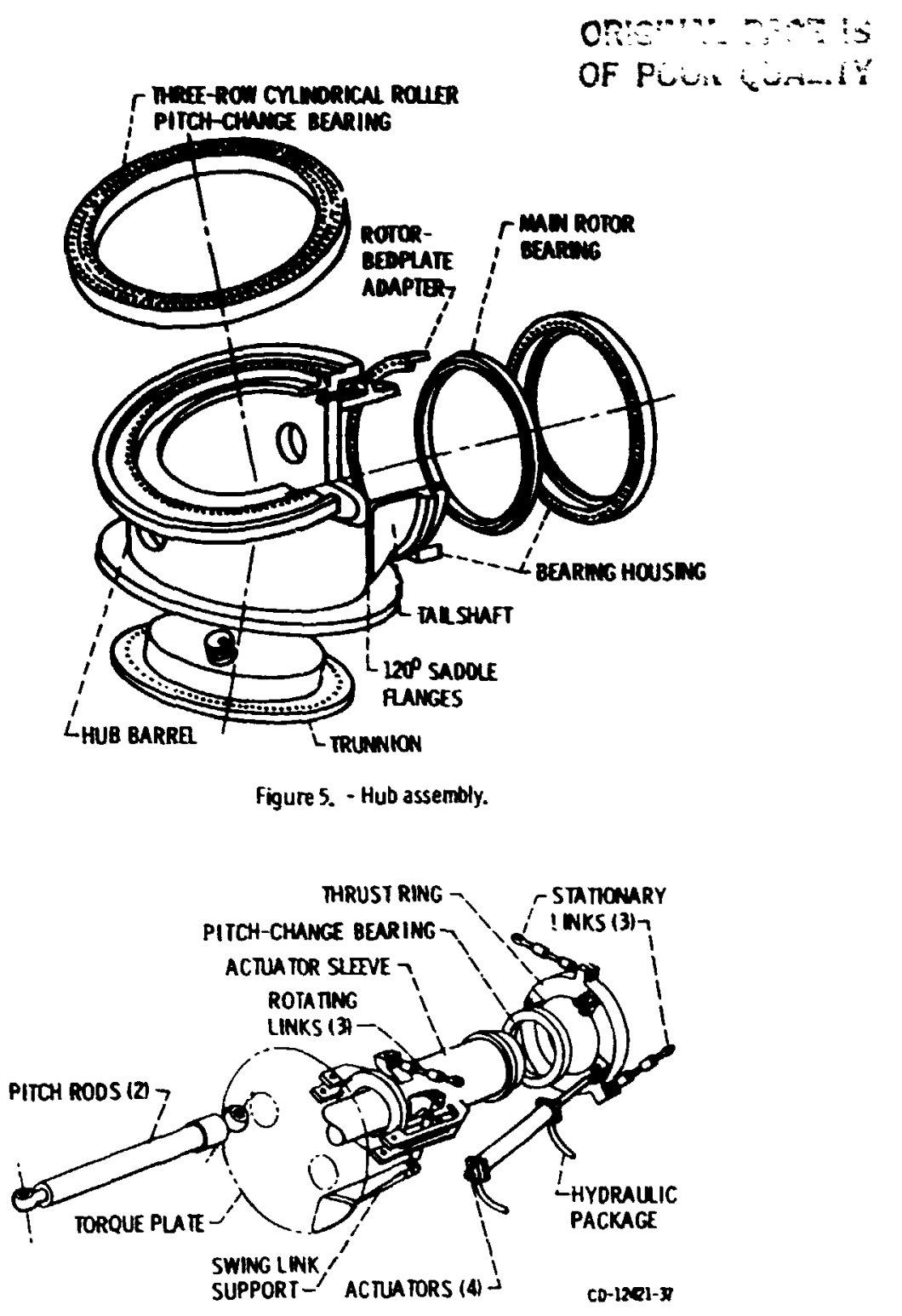

Figure 6. - Pitch-change mechanism.

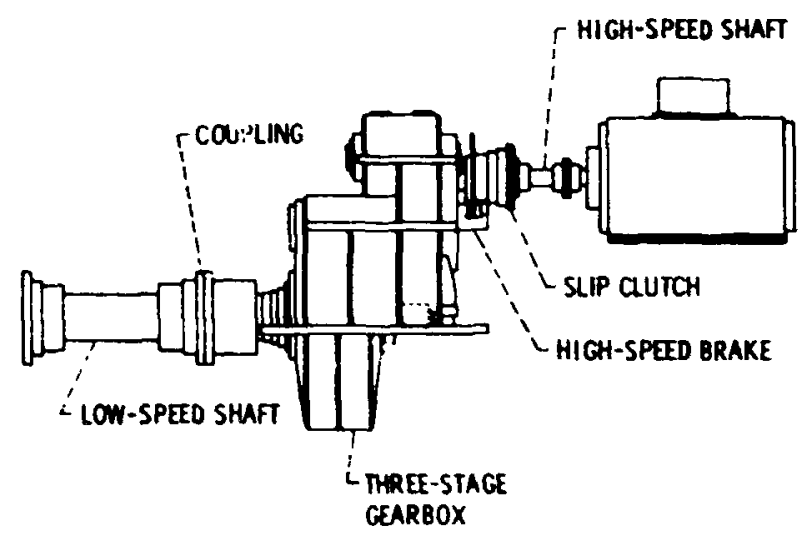

Figure 7. - Drive train assembly. 
Can a. …

of How: $\therefore:$

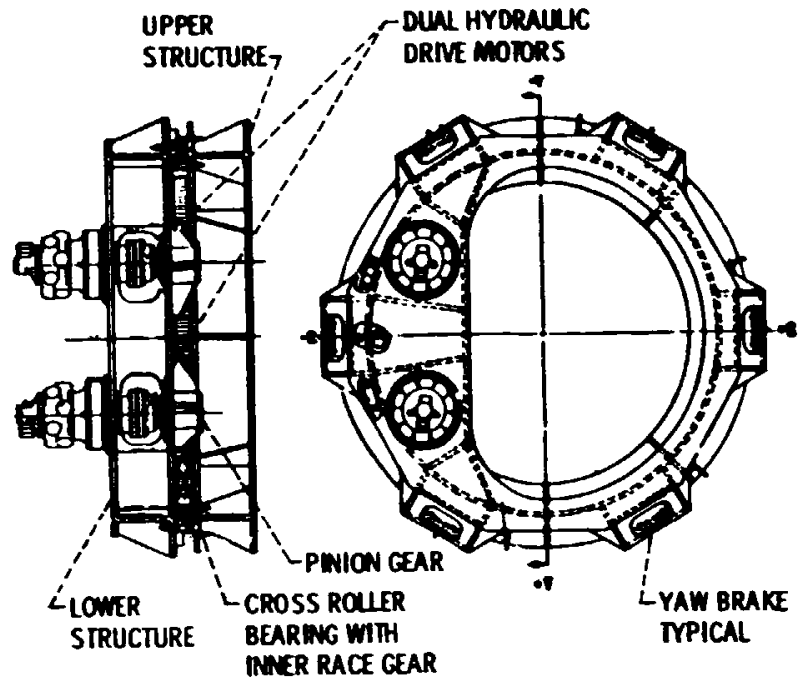

figure 8. - Yaw drive assembly.

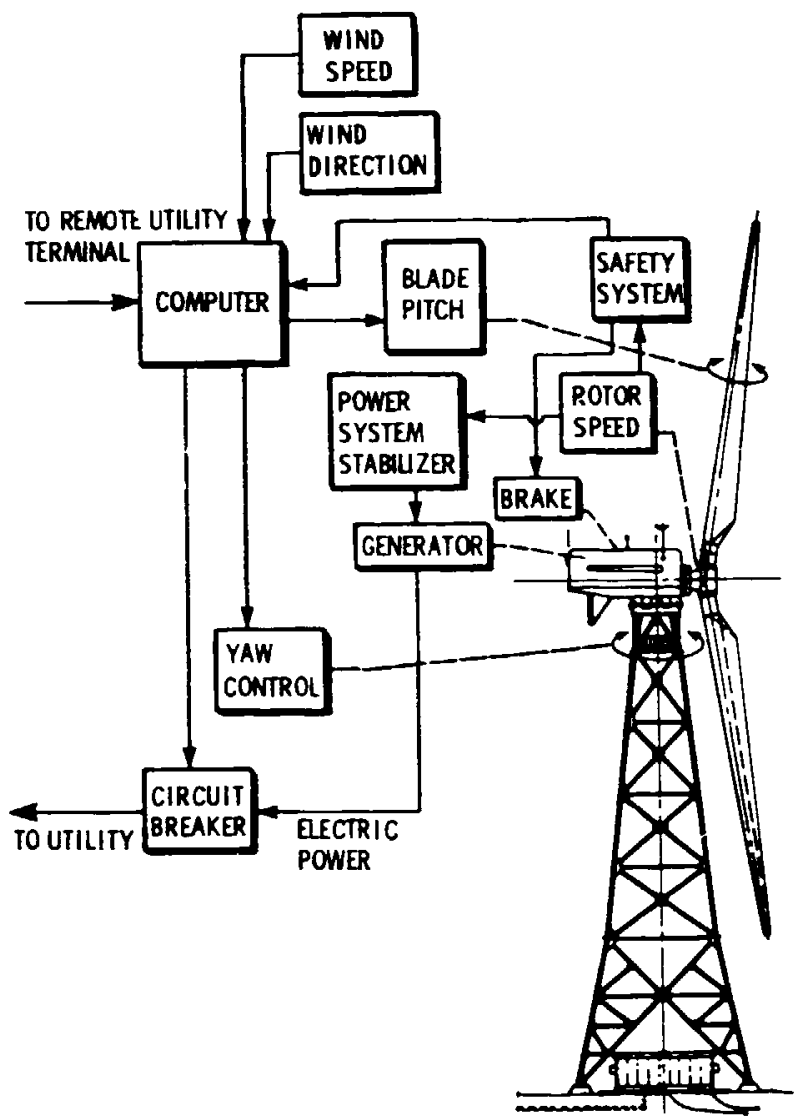

Figure 9. - Simplified Moo-l control schematic, 
Caiv: $\because \because \because \cdots$

OF PuU. B s

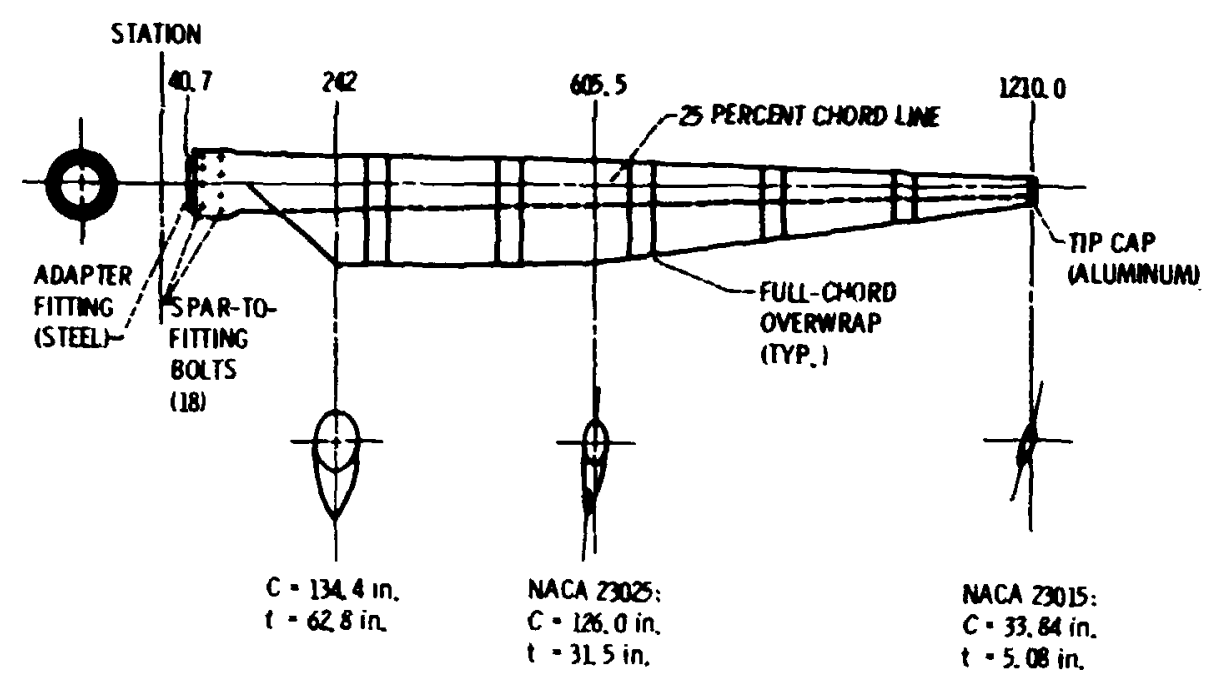
Figure 10. - MOD-l composite blade. Twist, $11^{\circ}$ linear (root to tip); airfoil, 2000 series; weight with actapter.
26840 ib.

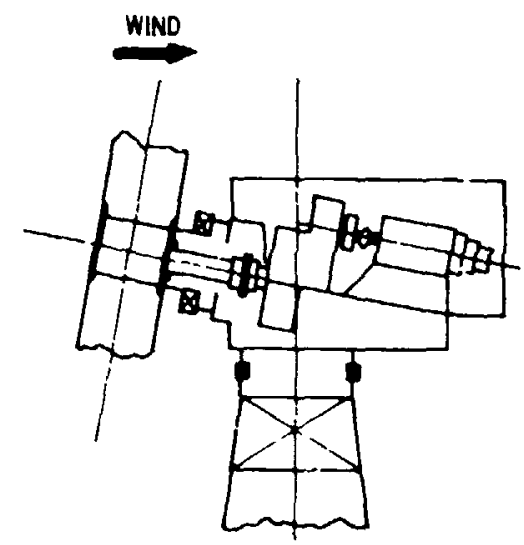

(a)

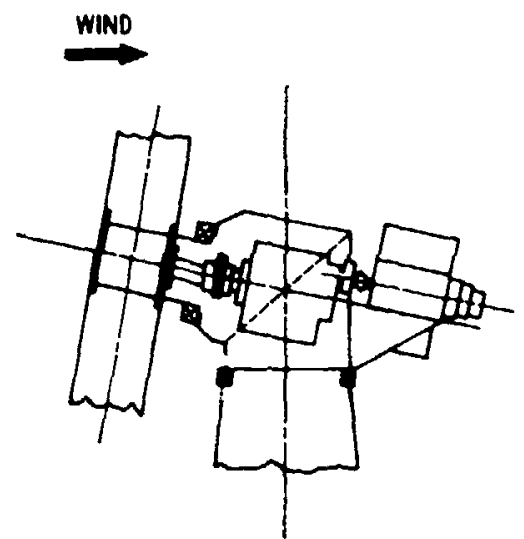

(b)

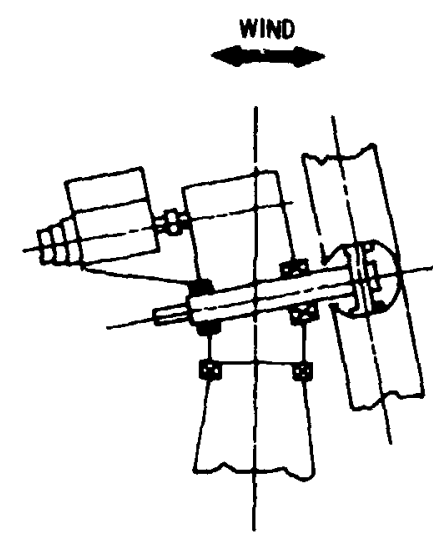

(c)

(a) Design concept 1 - reduced Mod-1: fixed hub; two blades; upwinc rotor; partial-span control; Mat-1 geartox; Mod-1 electric generator; truss tower (sott): tota! weight $30000 \mathrm{lb}$.

(b) Design concept 2 - epicyclic gear: fixed hub; three blades; upwind rotor; partial-span control; epicyclic geartoox; Mod-1 electric generator; shell tower isott: total weight $355000 \mathrm{lb}$.

(c) Jesign concept 3 - integral gatrox: teetered hut; two biades; downwind or upwind robr; prtial-span control; Mod-1 gear drive: Moot l electric generator; shell tower (soft); total weight 320000 it.

Figure 11. - Mod-1 trade-oft study wandidates. Favorable results as compa red with Mod-1 weight of $655000 \mathrm{lb}$. 

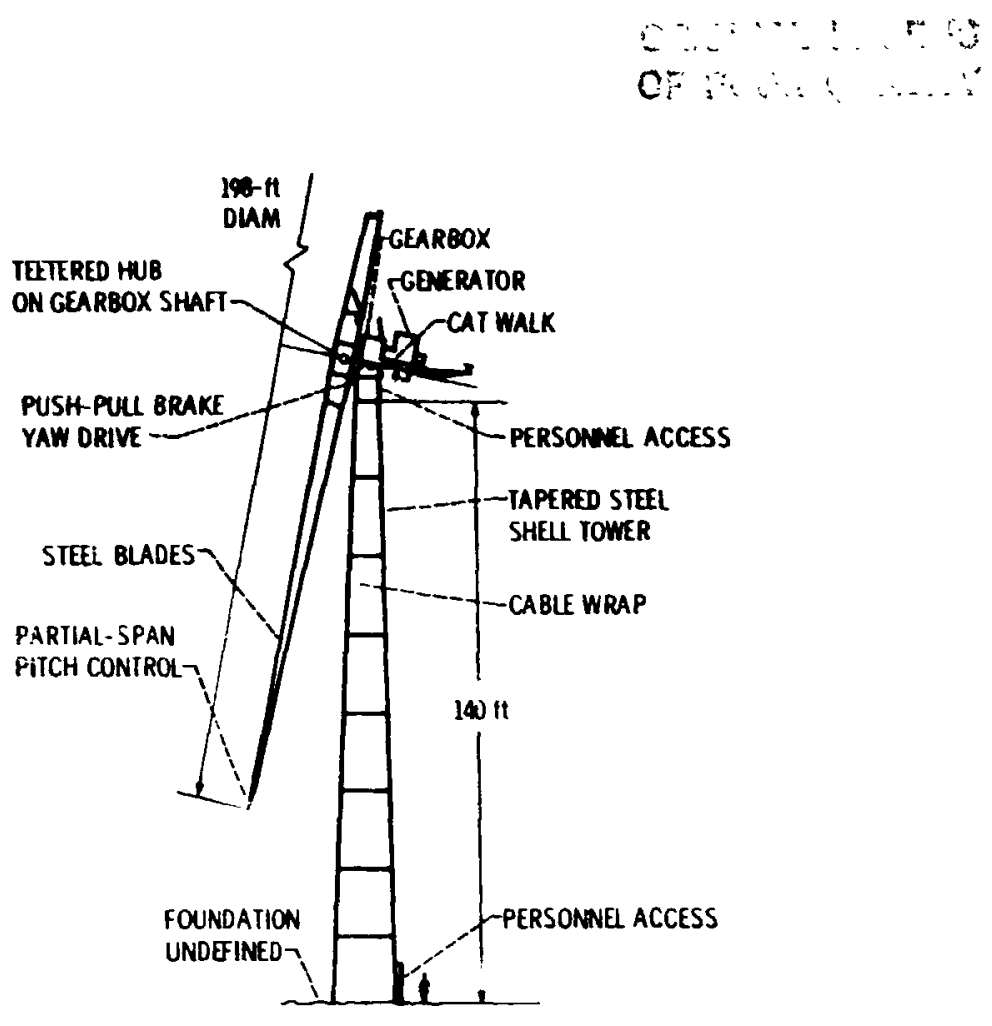

Figure 12 - Mod-1A configuration.

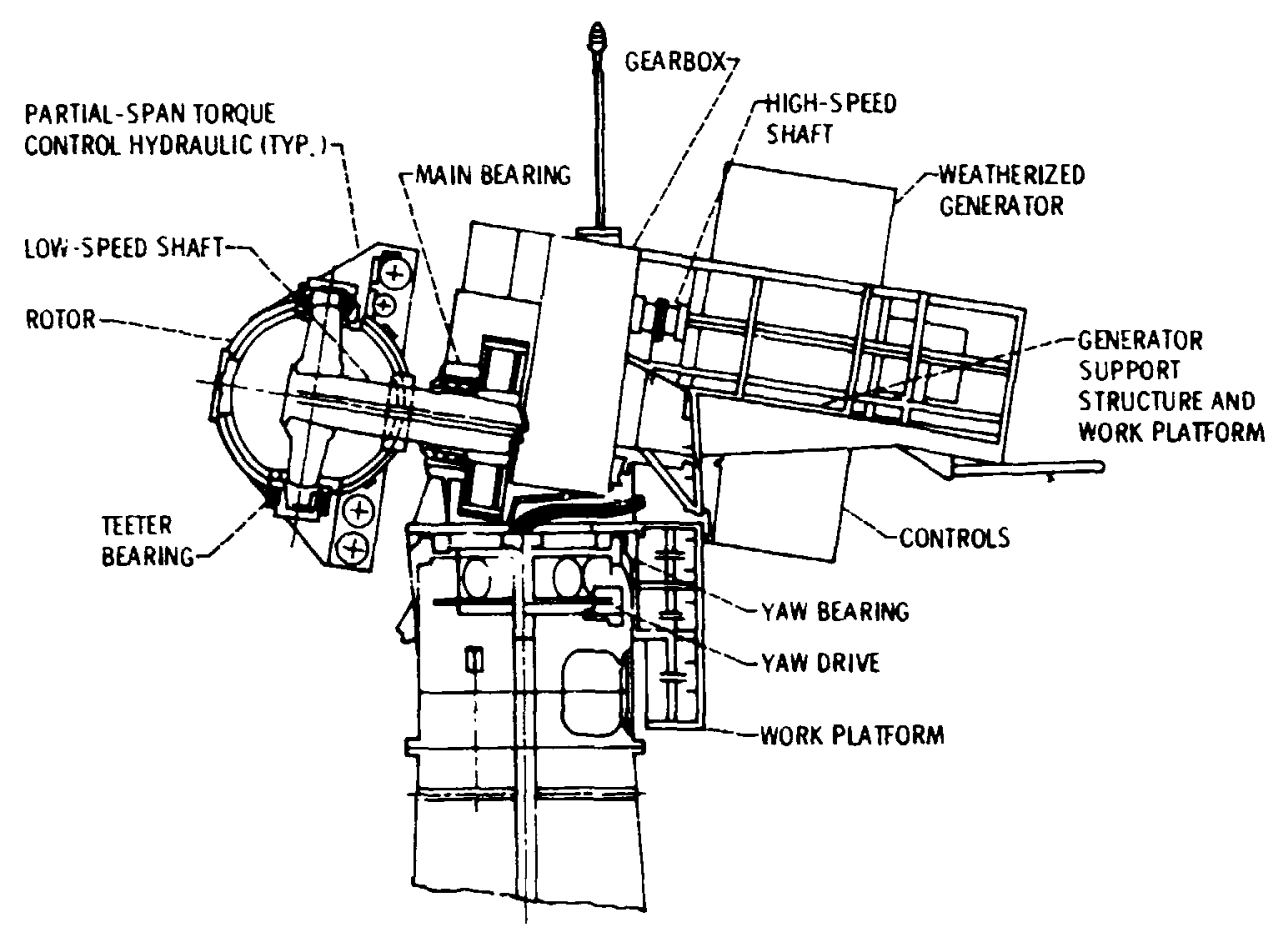

Figure 13, - Mod-1A nacelle. 


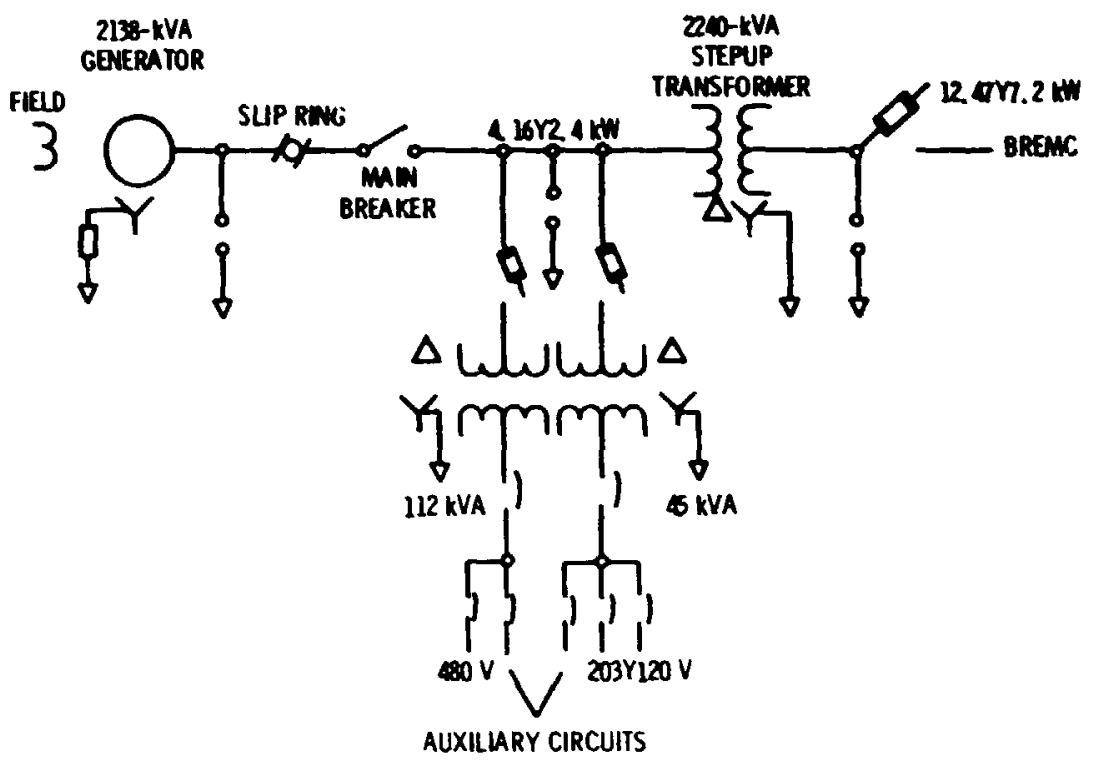

Figure 14. - Simplified one-line diagram of Moc-l power system.

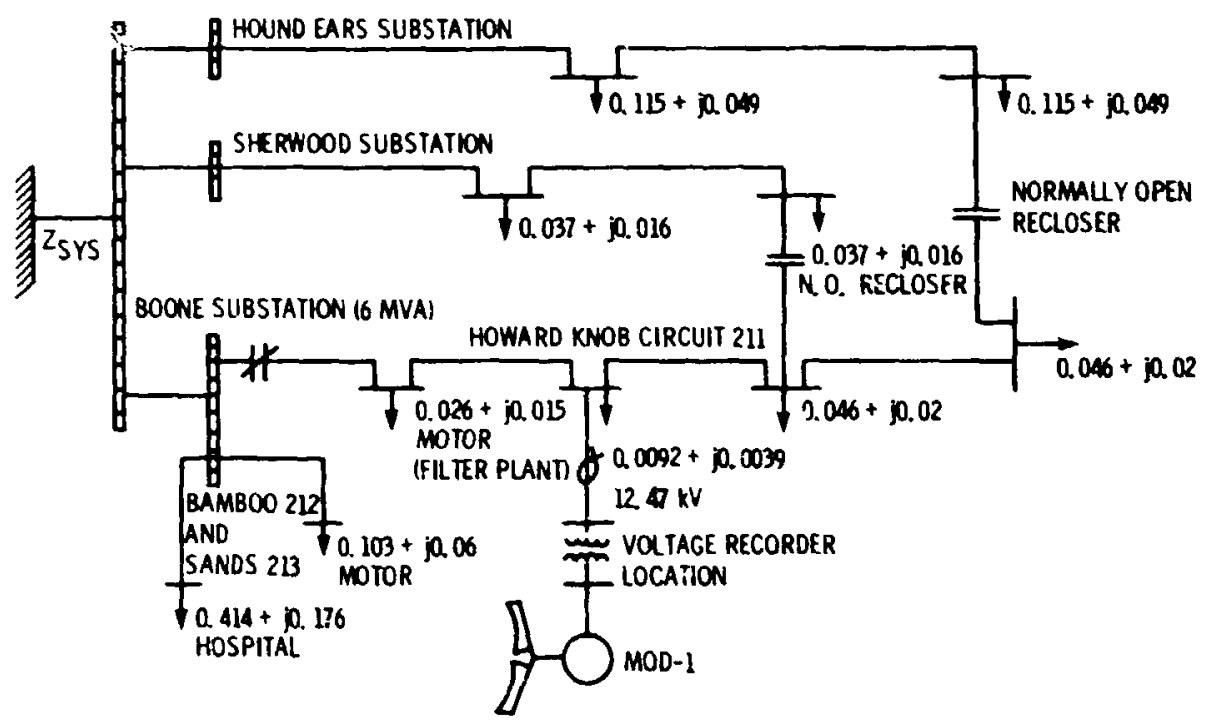

Figure 15. - Simpififed one-line Jiagram of Blue Ridge Electric Membership Corp. distribution system. (All loads on 10-MVA bose.) 
on:en:
or bus

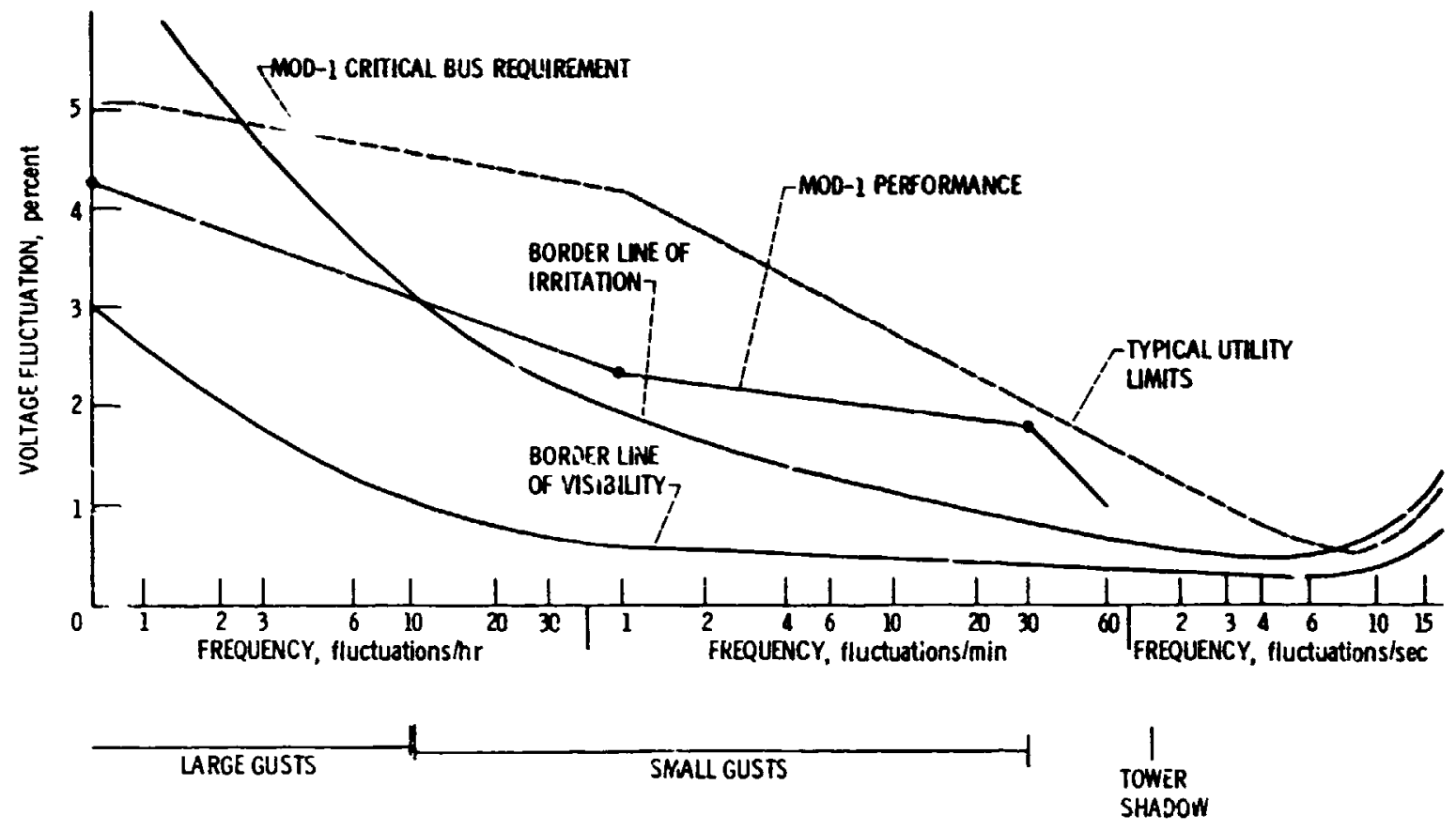

Figure 16. - Voltoge flicker characteristics. 
슨.?

of revar
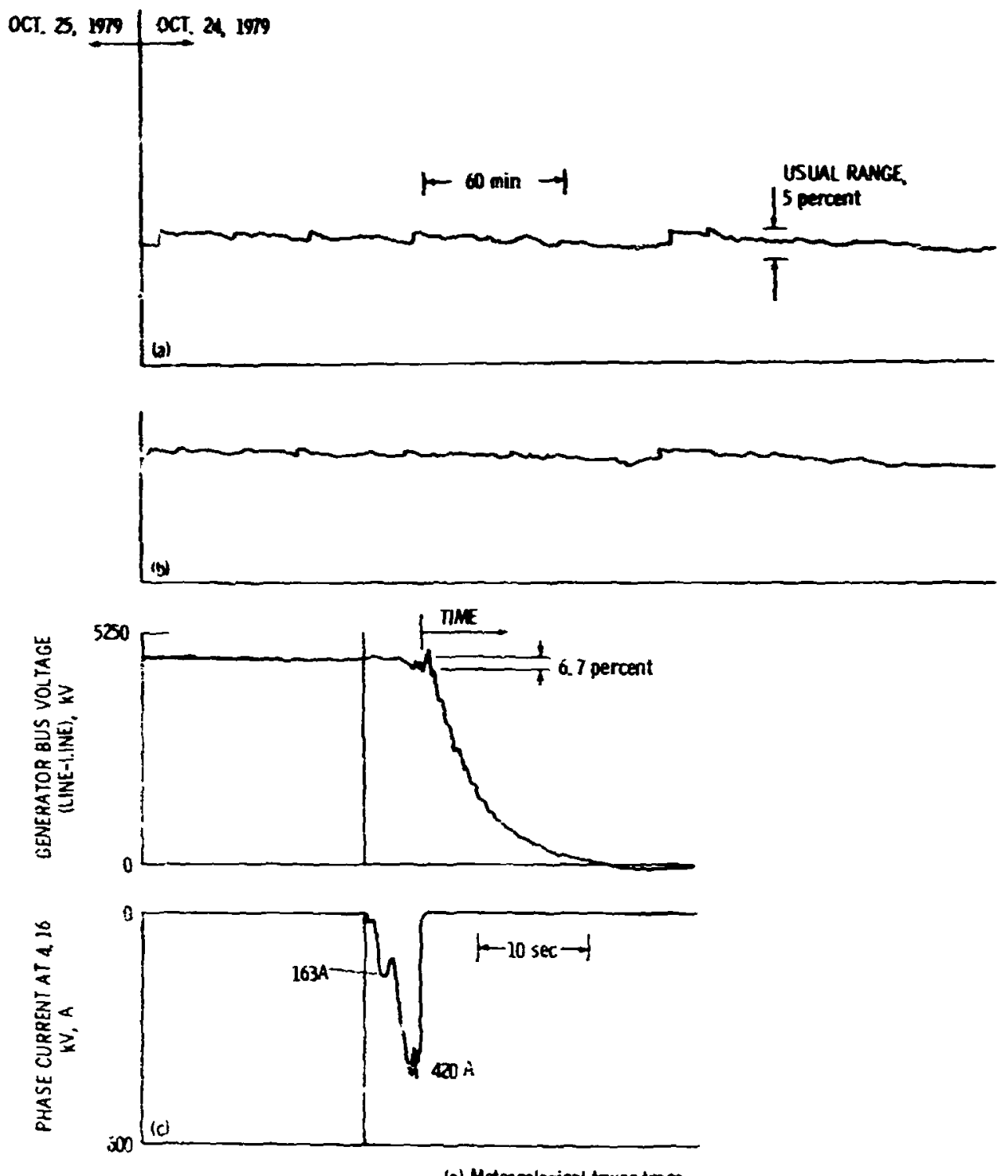

(a) Meteorological tower trace.

(b) Substation trace.

(c) Iransient on oct 241979.

Figure 17. - Utility volbage recorder trates and transient on OA 24 1999. Overtood shuiousns al 2253 2316 , and $2369 \mathrm{~V}$; 30 min slow at $2130 \mathrm{~V}$. 


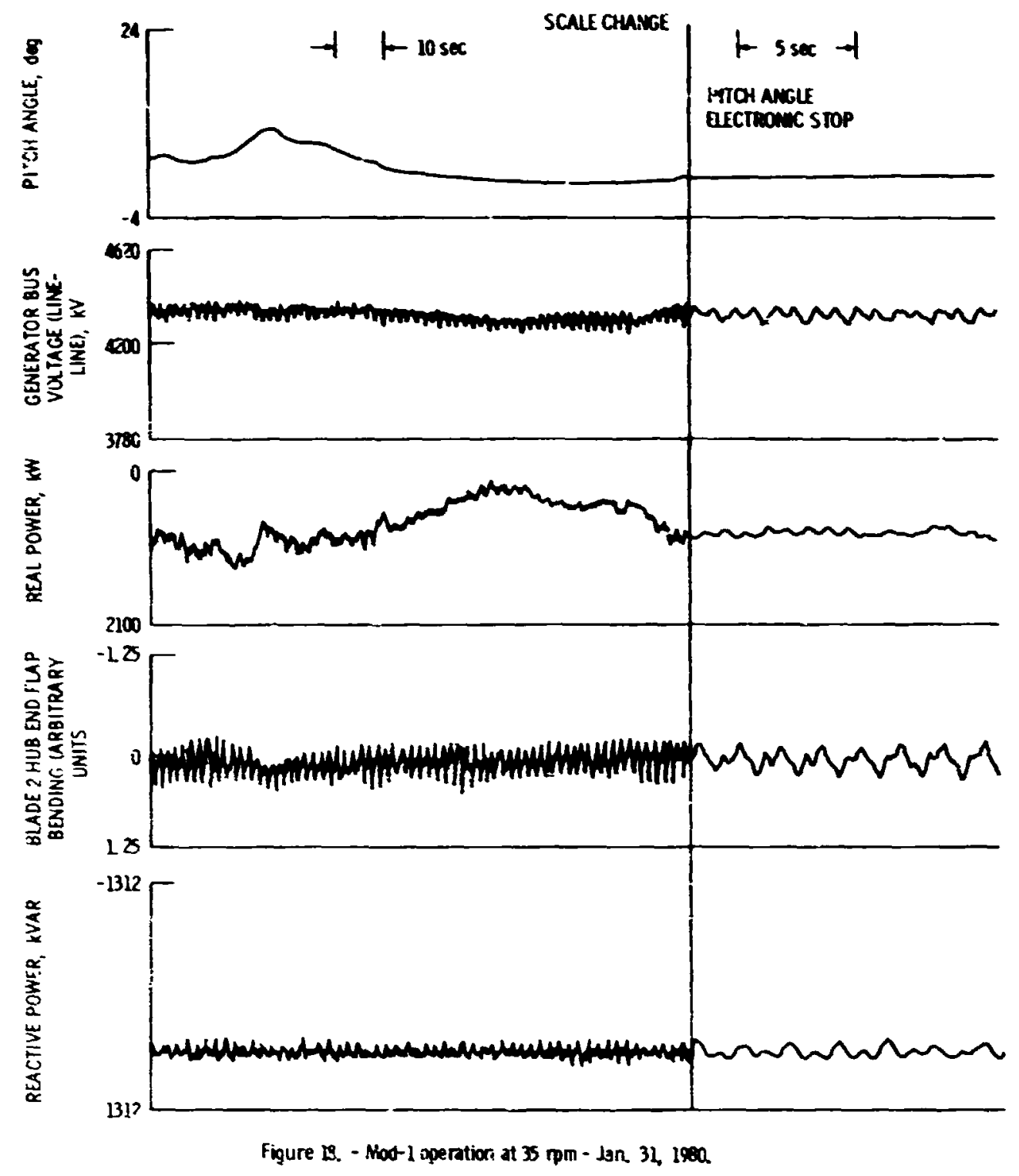




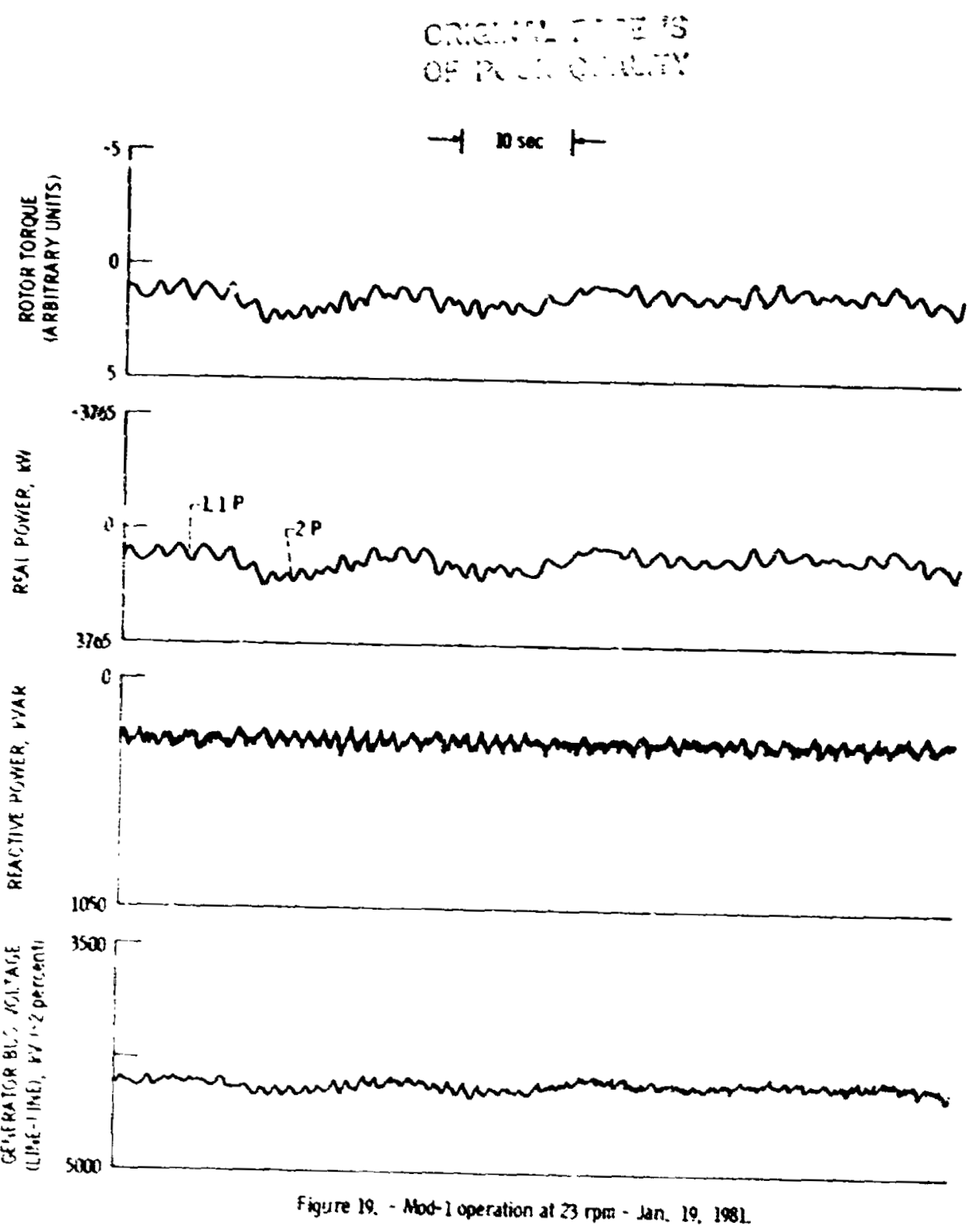




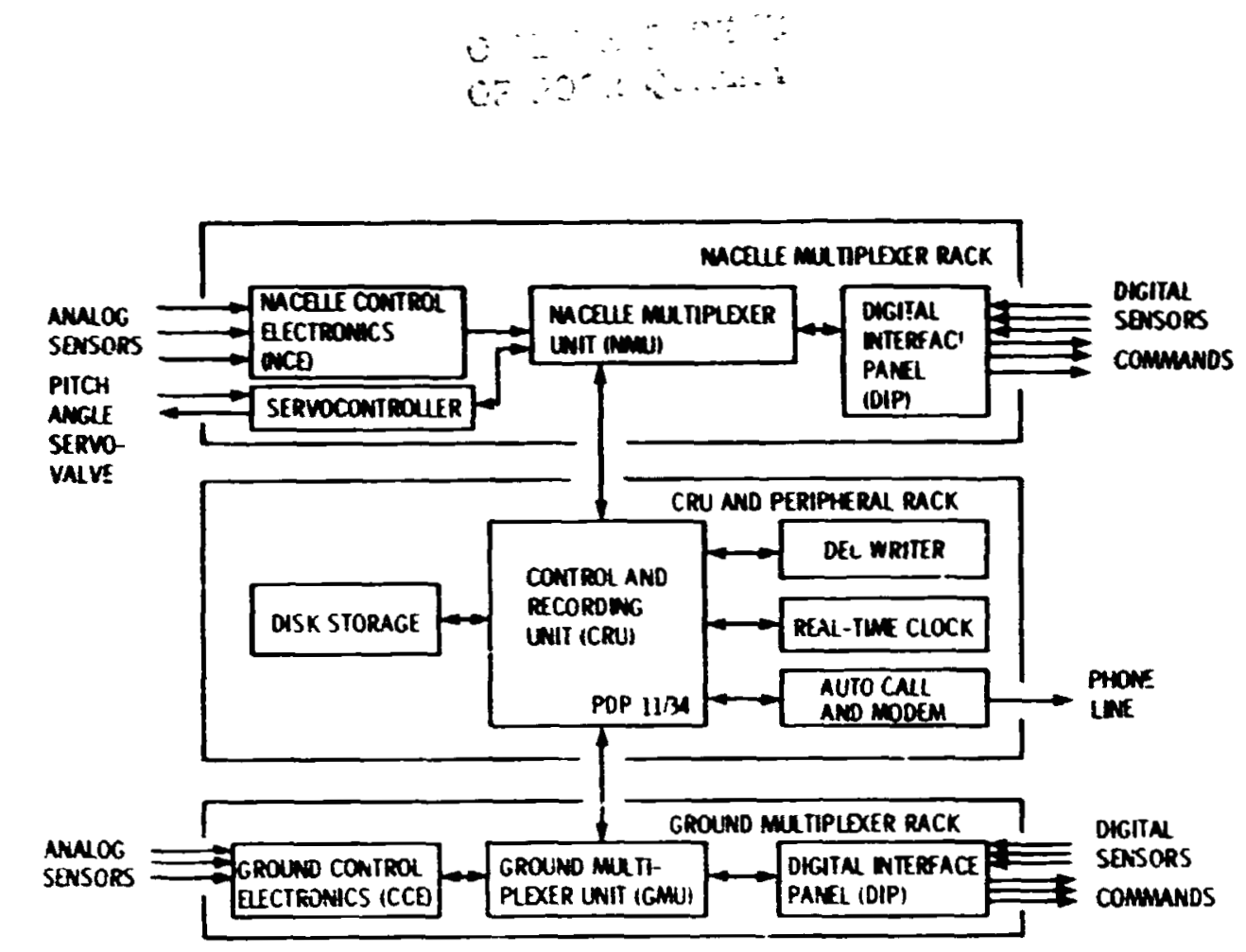

Figure 20. - Block diagrom of Mool-1 control system

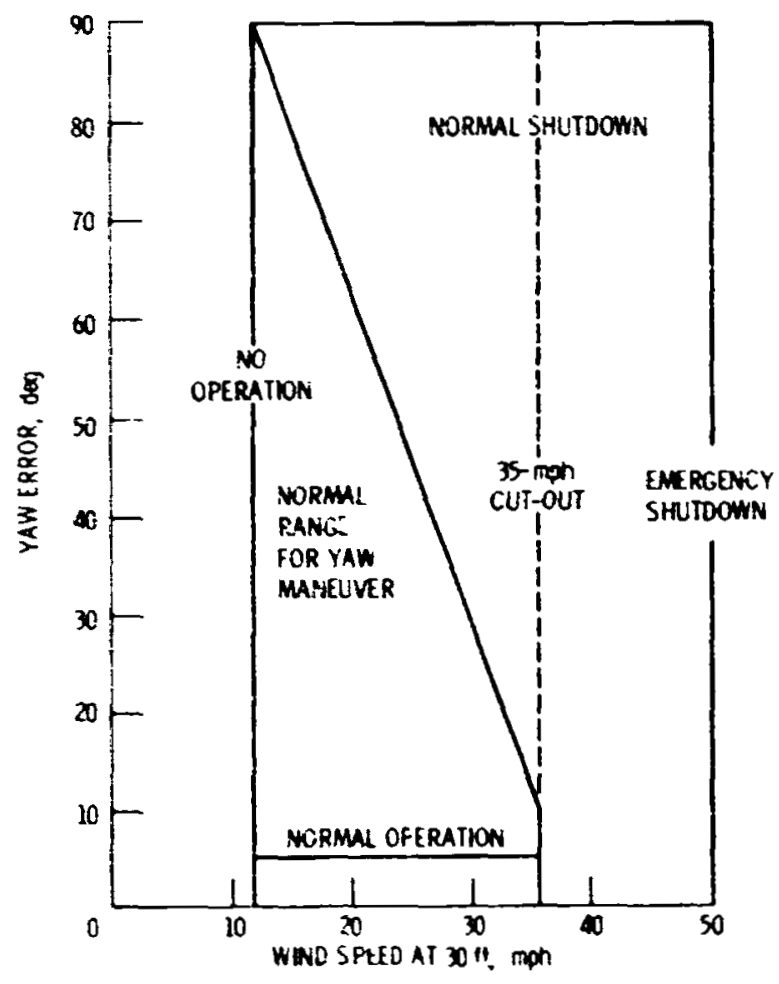

Figure 2L - MOC-1 operational envelope. 

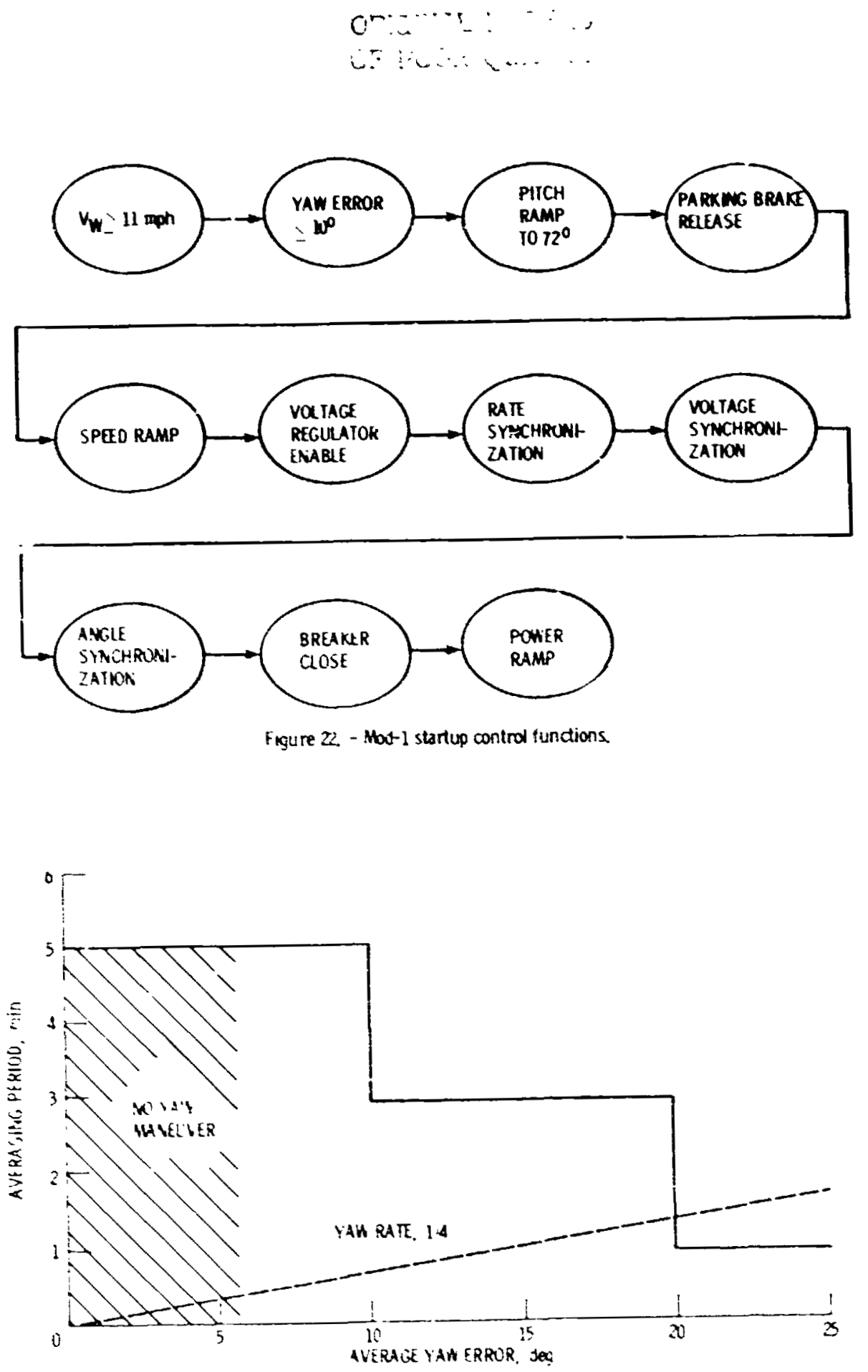

thegure 20. - Yaw wrrection averaging logic for Mod-1. 


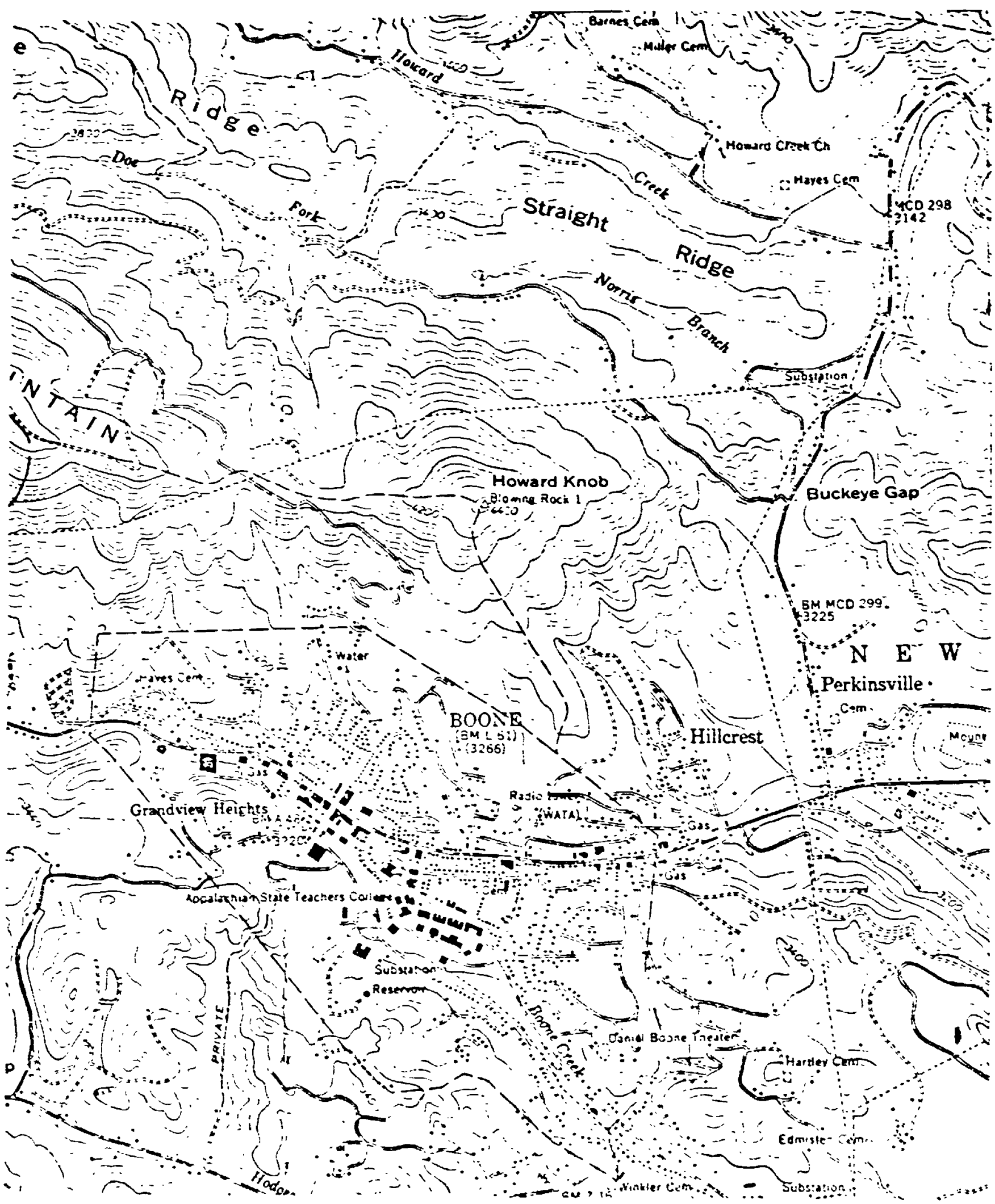




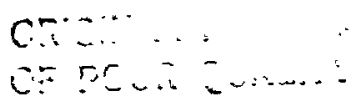

JOHNSON CIIY, TENM.

(5) (11)

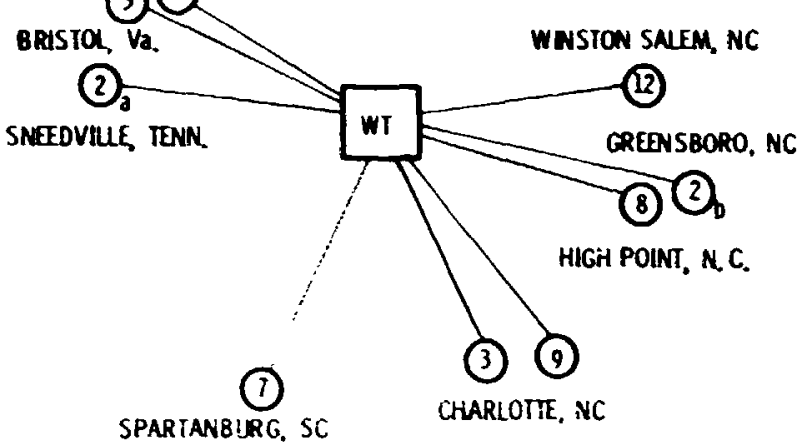

Figure $\boldsymbol{\sigma}$. - Ielevision stations received in Boone.

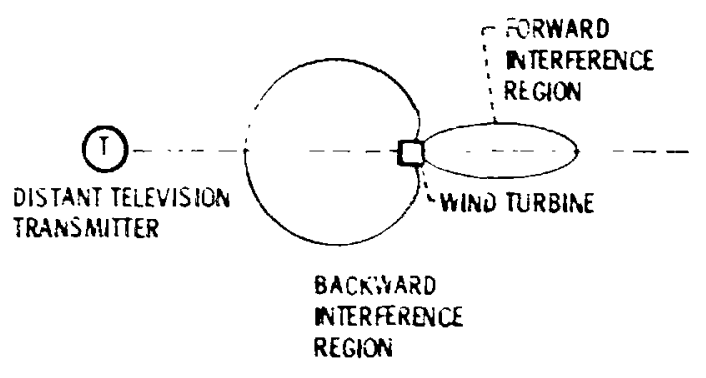

Figure 20. - Teievision forward and backward interference regions tor a wind turtine. 


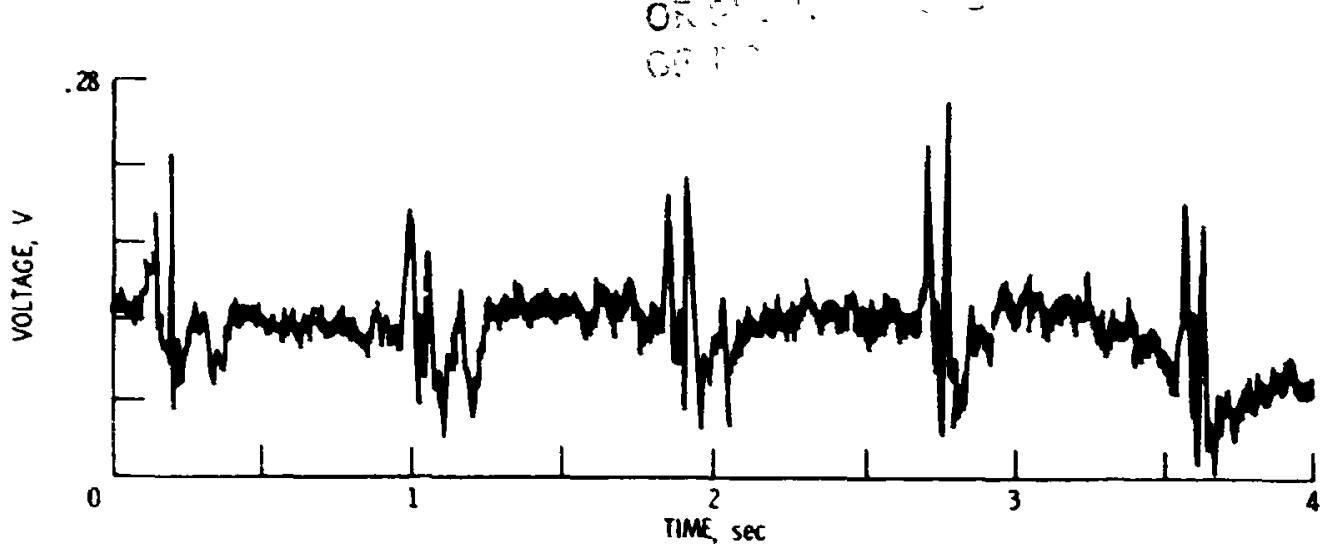

Figure 27. - Impulse sequence near Moo- l operating at $35 \mathrm{rpm}$ and generating $500 \mathrm{~kW}$ - Apr. 1, 1980.

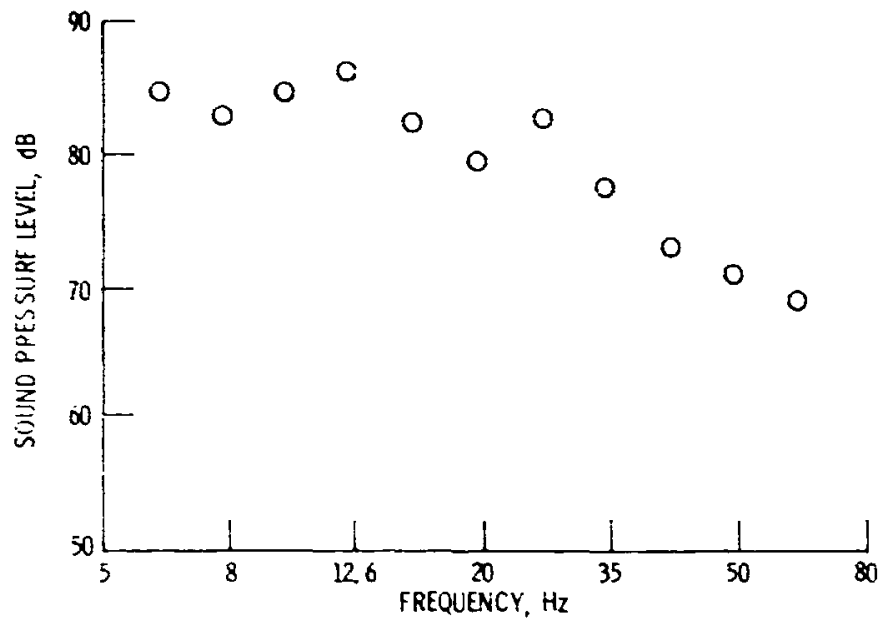

Fig. re 28. - Sound pressure levels $50 \mathrm{ft}$ i rom wind turbine for Mod-1 operating at $35 \mathrm{rpm}$ and generating $1000 \mathrm{~kW}-\mathrm{Feb} .12,1980$.

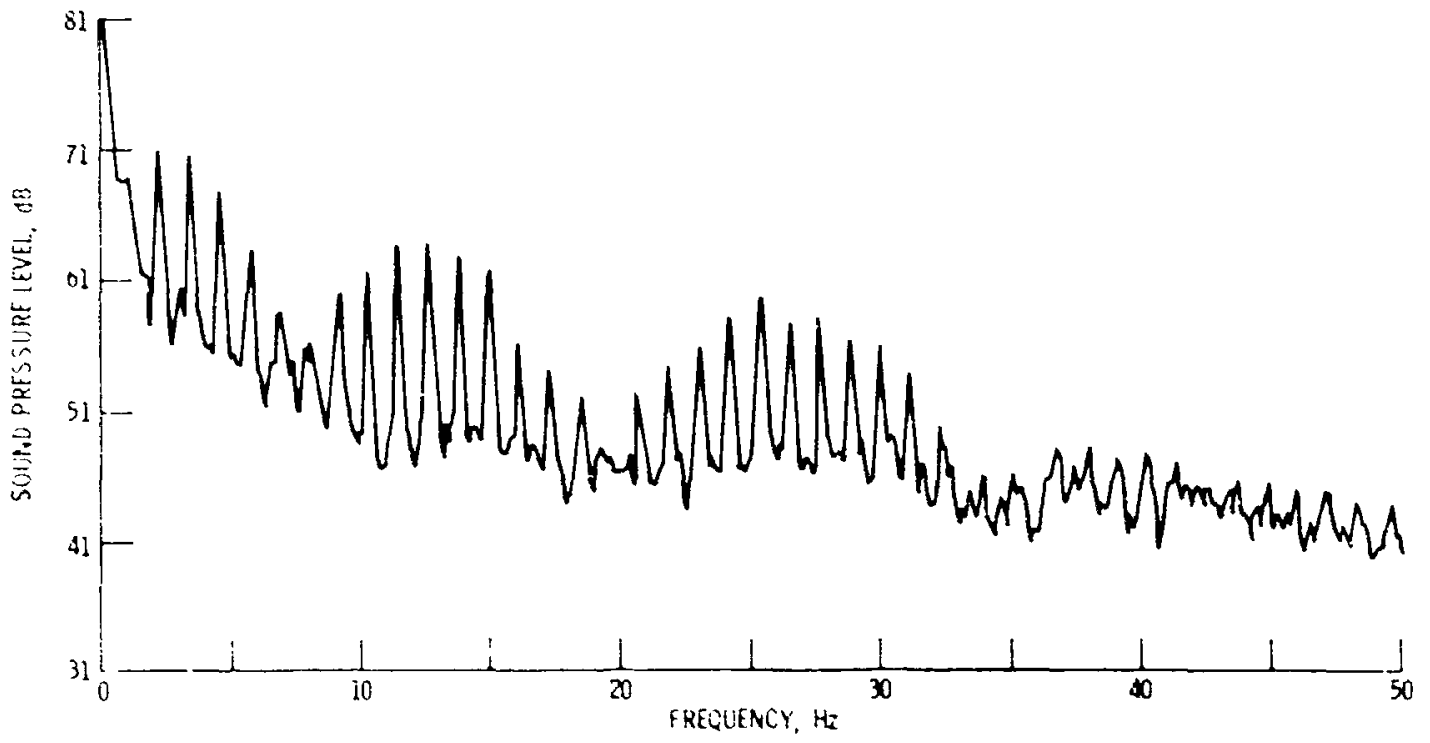

Figure 29. - Sound pressure level outside residence as a function of frequency; - 12:07 a. m., Mar. 31, 1980. 

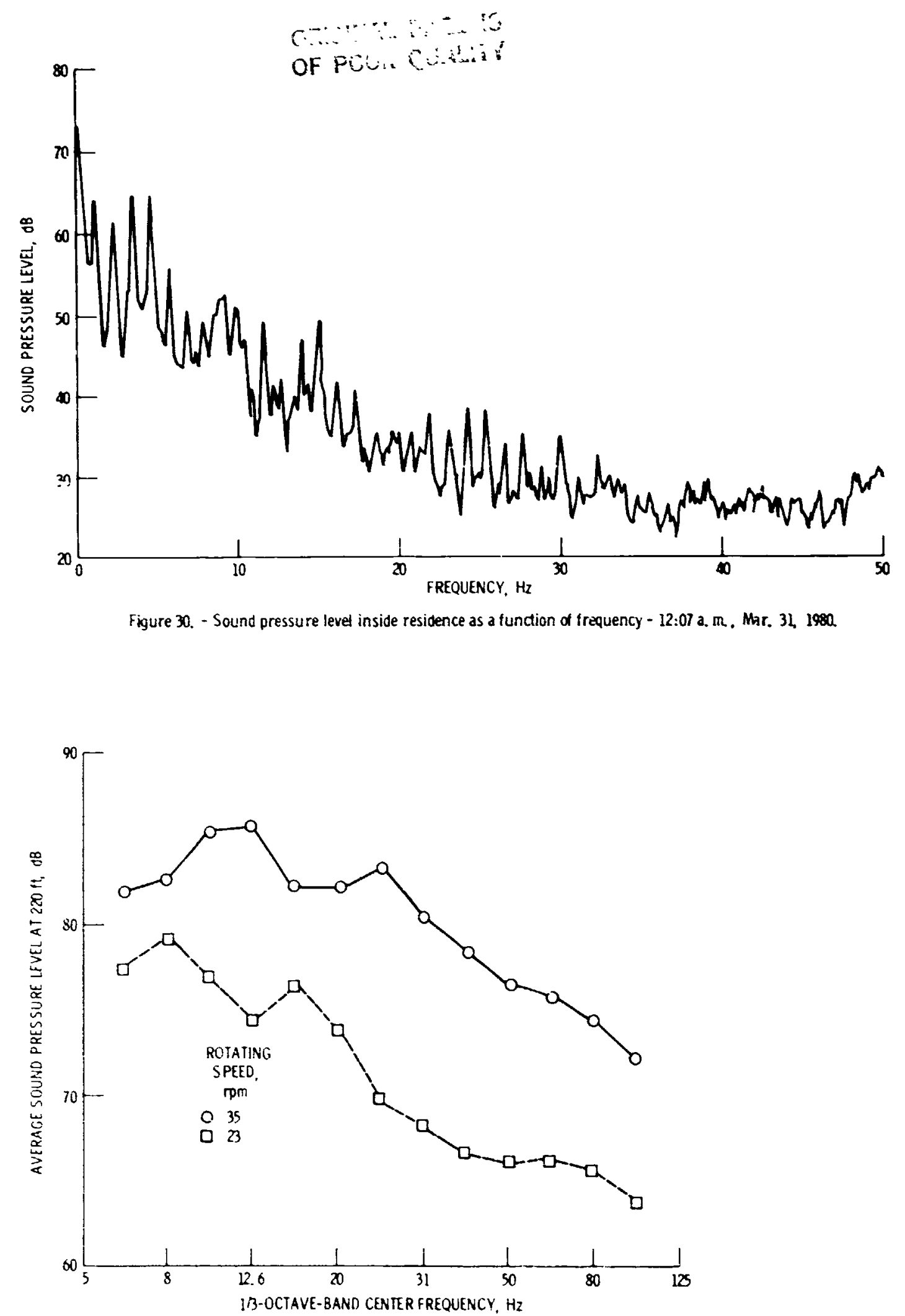

Figure 31. - Average suind pressure levels as a function of frequeno at 35 and $23 \mathrm{rpm}$ Each curve represents average sound pressure levels for seven sets of data - with different but comparable wind conditions and load. 

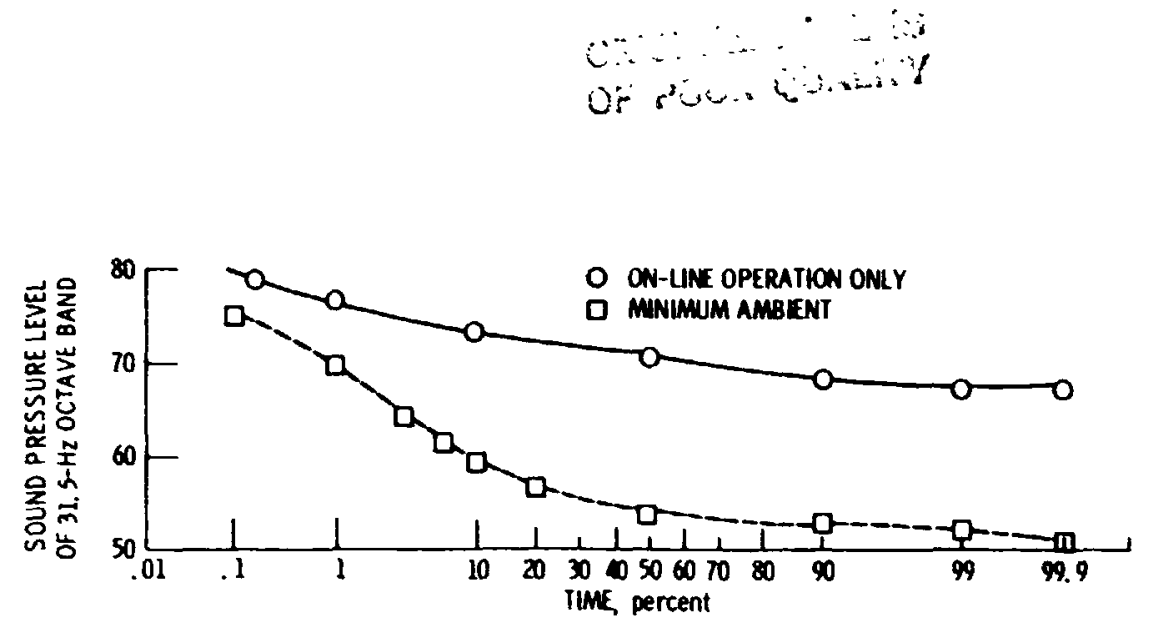

Figure 32 - Percentege of time sound exceeded specified levels - near-field sound pressure level distribution at $1269 \mathrm{ft}$ from center of tower.

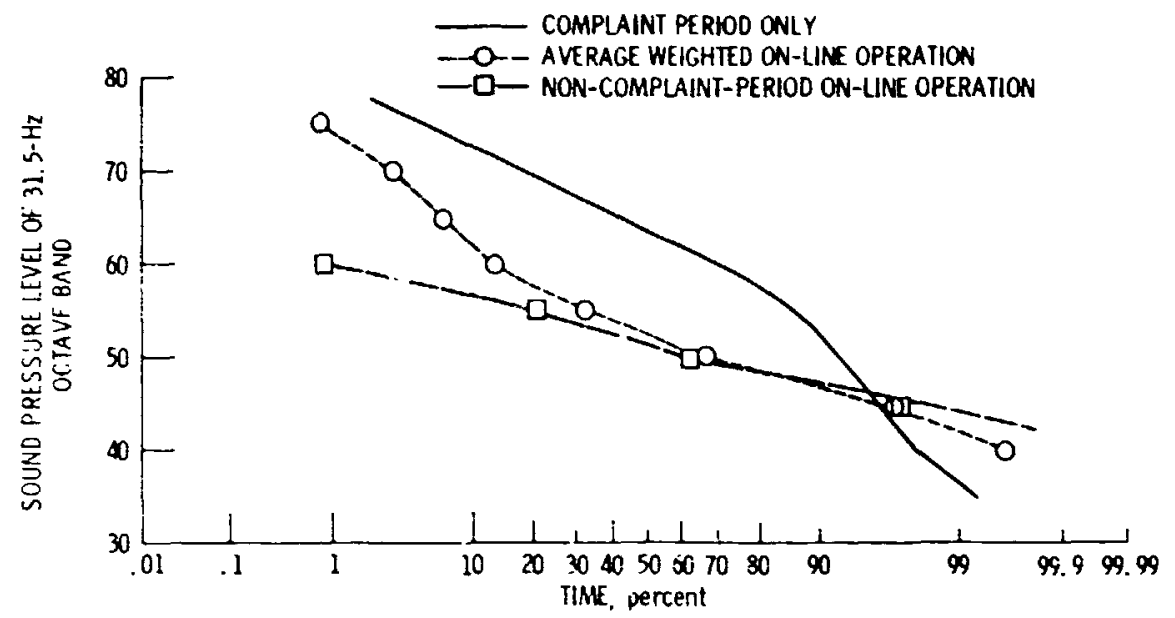

Figure 33. - Percentage of time sound exceeded specified levels-estimated long-period sound pressure level distribution at far-field position I for on-line operation only. (Assumes levels corresponding to those of the complaint period for 16 total time.)

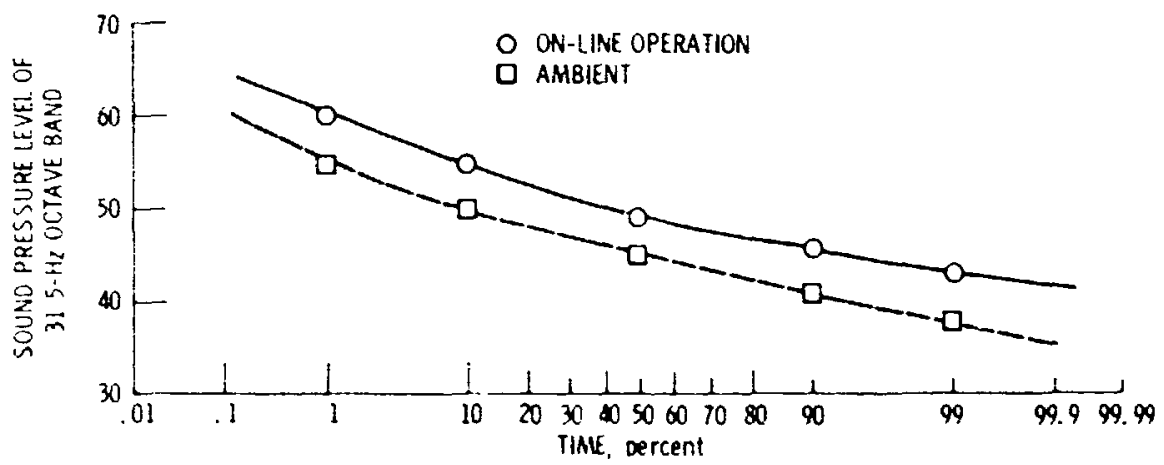

Figure 34 - Percentaje of time sound exceeded specified levels-sound pressure level distribution at far-field position 2 . 
Oanen?

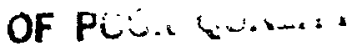

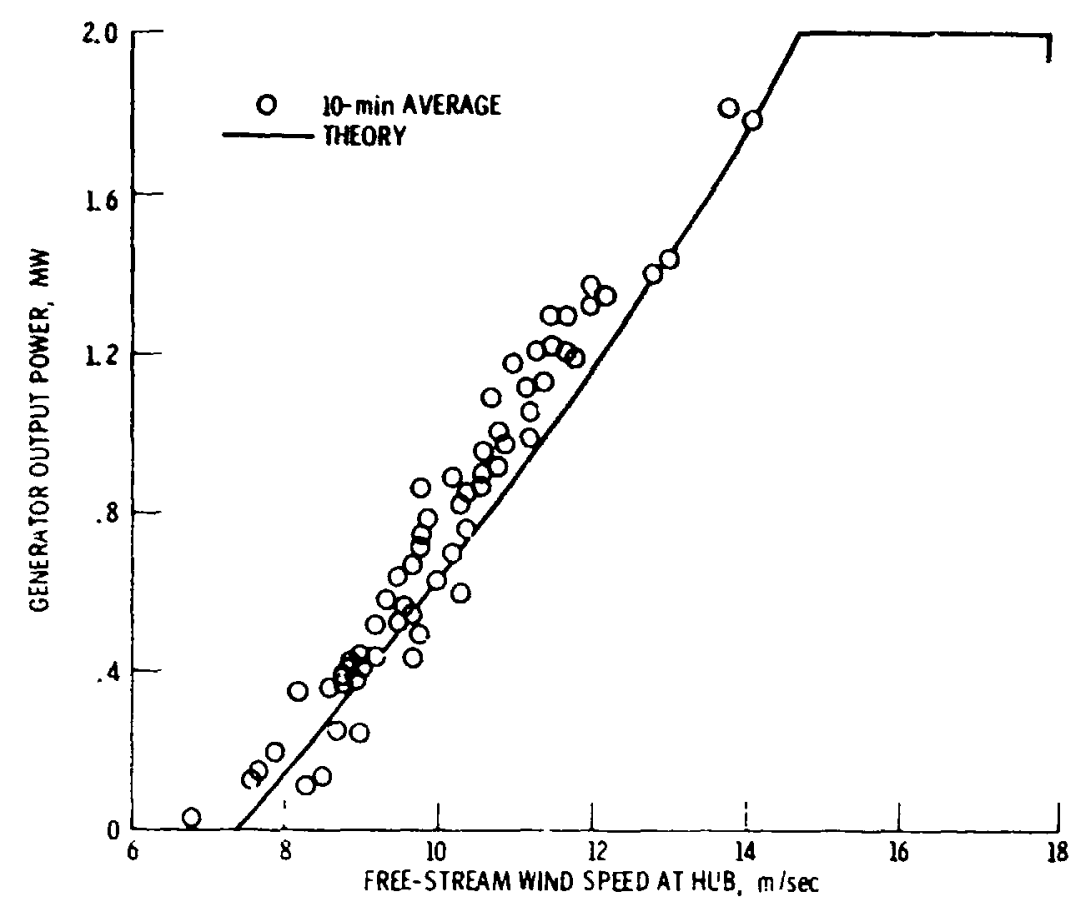

Figure 35. - Output posver of Moor- 2- MW wind turtine.

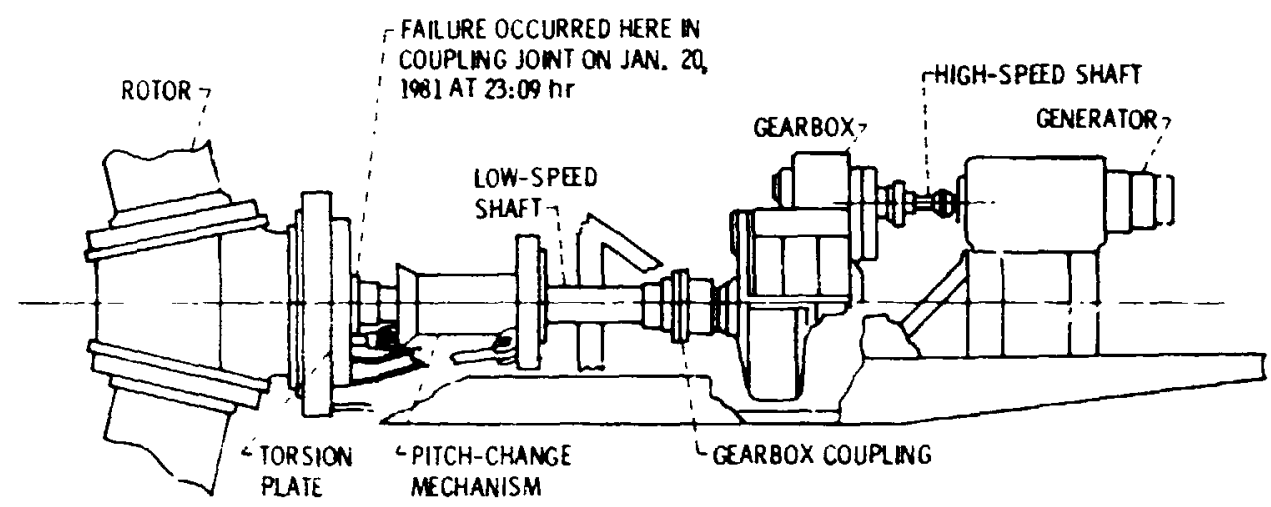

Figure 36. - Mat-1 drive train. 


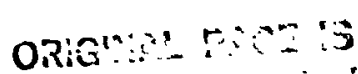

OF POOB: $\quad \cdots:$ :

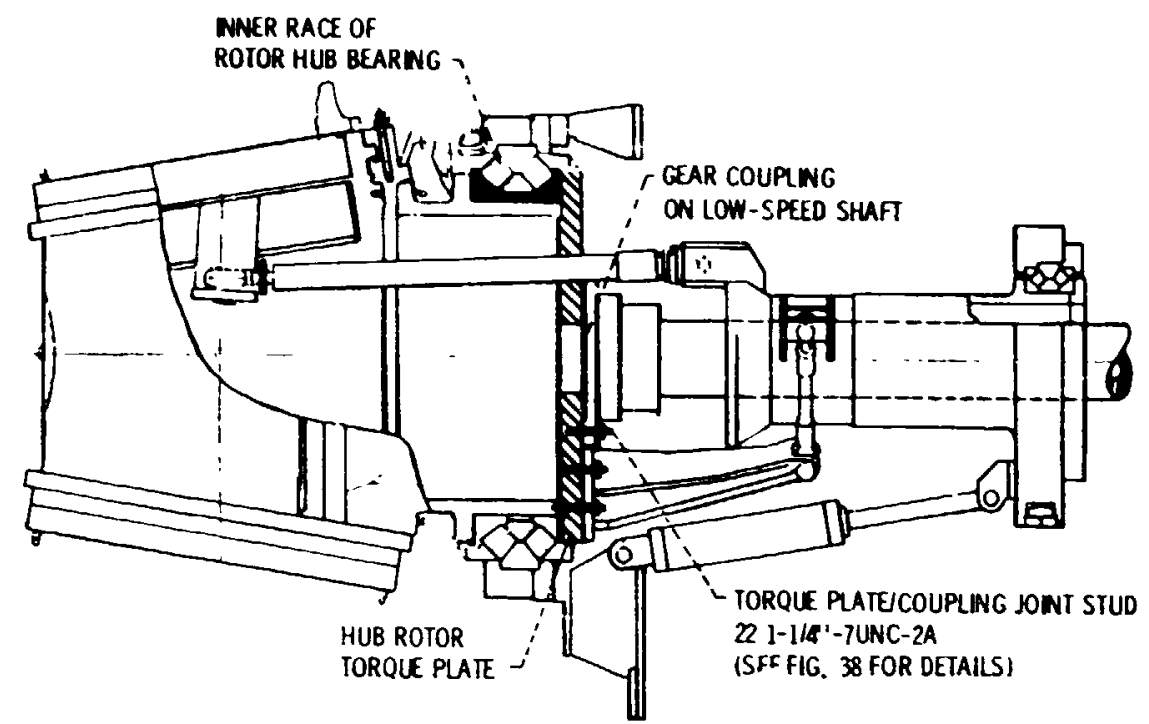

Figure 37. - Section view of hub-shaft interface showing stud location.

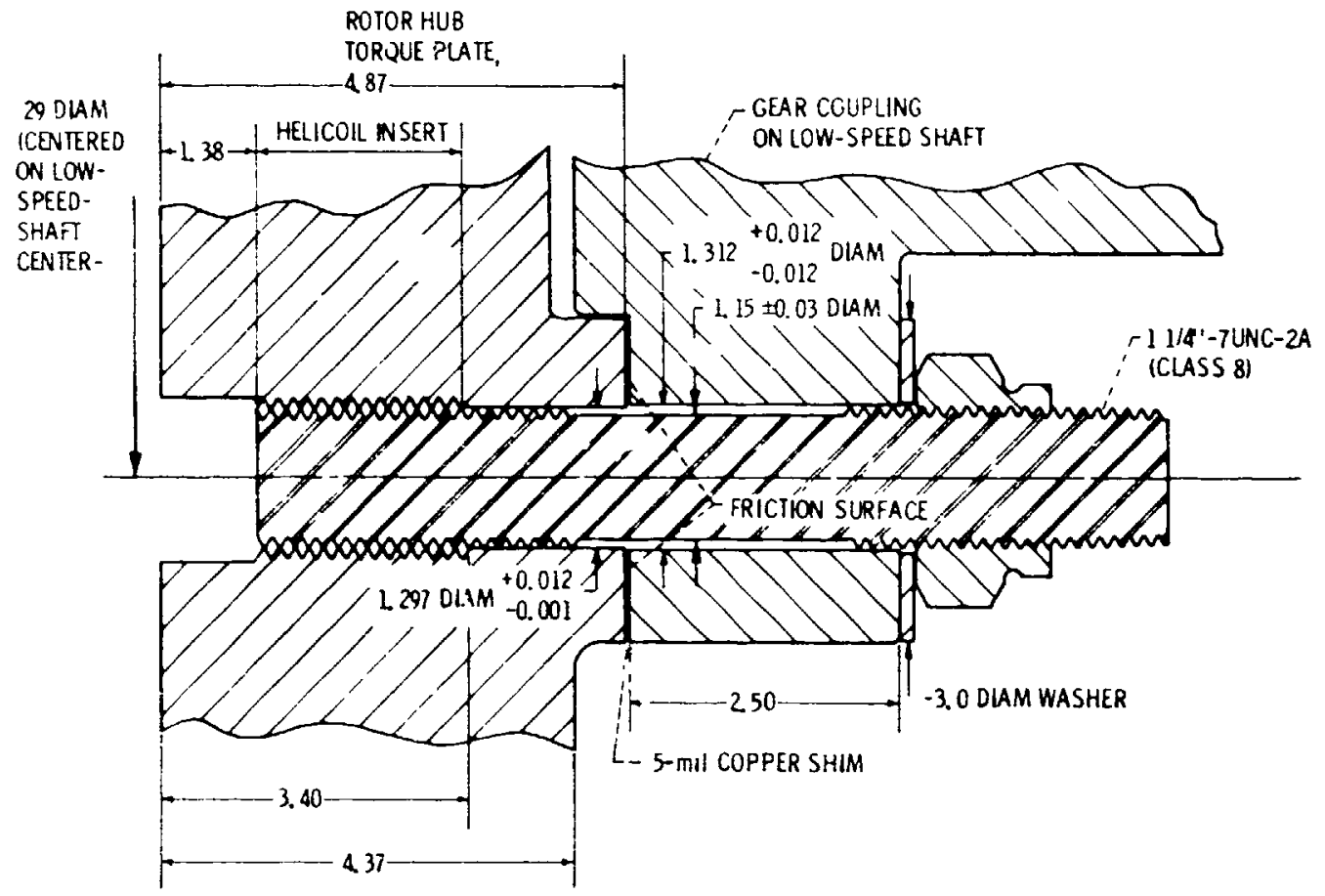

ix, ife 38, - Torque plateicoupling pornt istud detall. Dimensions are in inches. 